\title{
New Series of VEGFR-2 Inhibitors and Apoptosis Enhancers: Design, Synthesis and Biological Evaluation
}

\author{
Abdallah E Abdallah (D)', Reda R Mabrouk', Mohamed R Elnagar $\mathbb{D}^{2}$, Amel Mostafa Farrag ${ }^{3}$, \\ Mohamed H Kalaba $\mathbb{D}^{4}$, Mohamed H Sharaf ${ }^{4}$, Esmail M El-Fakharany $\mathbb{D}^{5}$, Dina Abed Bakhotmah (1) ${ }^{6}$, \\ Eslam B Elkaeed (1D ${ }^{7}$, Maged Mohammed Saleh AI Ward (D) ${ }^{1}$ \\ 'Pharmaceutical Medicinal Chemistry \& Drug Design Department, Faculty of Pharmacy (Boys), Al-Azhar University, Cairo, I I 884, Egypt; ${ }^{2}$ Department \\ of Pharmacology and Toxicology, Faculty of Pharmacy, Al-Azhar University, Cairo, II 884, Egypt; ${ }^{3}$ Pharmaceutical Chemistry Department, Faculty of \\ Pharmacy (Girls), Al-Azhar University, Cairo, Egypt; ${ }^{4}$ Botany and Microbiology Department, Faculty of Science, Al-Azhar University, Cairo, II884, \\ Egypt; ${ }^{5}$ Protein Research Department, Genetic Engineering and Biotechnology Research Institute, City of Scientific Research and Technological \\ Applications, New Borg El Arab, Egypt; ${ }^{6}$ Chemistry Department, King Abdulaziz University, Jeddah, Kingdom of Saudi Arabia; ${ }^{7}$ Department of \\ Pharmaceutical Sciences, College of Pharmacy, AlMaarefa University, Riyadh, I37I3, Saudi Arabia
}

Correspondence: Abdallah E Abdallah; Maged Mohammed Saleh AI Ward, Pharmaceutical Medicinal Chemistry \& Drug Design Department, Faculty of Pharmacy (Boys), Al-Azhar University, Cairo, II884, Egypt, Email Abdulla_emara@azhar.edu.eg; majedI000ward@hotmail.com

Background: Cancer is still a major world health threat, causing a high rate of mortality. VEGFR-2 inhibitor anticancer agents are of great significance. However, they showed some serious side effects.

Purpose: To discover new effective and safer anticancer agents, a new series of piperazinylquinoxaline-based derivatives was designed and synthesized on the basis of the pharmacophoric features of VEGFR-2 inhibitor drugs.

Methods: The new candidates were evaluated against A549 lung cancer cells, HepG-2 hepatoma cells, Caco-2 colon cancer cells, MDA breast cancer cells, and VEGFR-2 kinase. Moreover, cell cycle kinetics and apoptosis rates were studied in HepG-2 cells treated with compound 11, which was the most promising candidate.

Results: The new derivatives revealed better antitumor results $\left(\mathrm{IC}_{50}\right.$ from 6.48 to $\left.38.58 \mu \mathrm{M}\right)$ against the aforementioned cancer cell lines than sorafenib. Also, the new candidates showed VEGFR-2 inhibition with $\mathrm{IC}_{50}$ values ranging from 0.19 to $0.60 \mu \mathrm{M}$ compared to 0.08 $\mu \mathrm{M}$ for sorafenib. Compound 11, meanwhile, showed $\mathrm{IC}_{50}$ values equal to $10.61,9.52,12.45,11.52$, and $0.19 \mu \mathrm{M}$ against the cancer cell lines and VEGFR-2, respectively. Moreover, compound 11 raised the apoptosis rate in HepG-2 cells from 5\% to 44\% and caused 4, 2.3, and 3-fold increases in BAX/Bcl-2 ratio, caspase-3 level, and P53 expression, respectively, compared to control untreated cells. Finally, the new derivatives displayed the correct binding mode into VEGFR-2 kinase pocket, giving interactions with the essential residues.

Conclusion: This work suggests that compound $\mathbf{1 1}$ is a very significant anticancer candidate, and piperazinylquinoxaline is an important scaffold in the development of new potential effective and safer VEGFR-2 inhibitor agents.

Keywords: anticancer, apoptosis, molecular modeling, piperazinylquinoxaline, VEGFR-2 kinase, Western blot

\section{Introduction}

Cancer is still a significant health issue. ${ }^{1}$ It is a primary cause of death all over the world. ${ }^{2,3}$ Globally, huge efforts have been done to control cancer. However, the incidence and mortality of cancer are growing at a high rate. ${ }^{2}$ Worldwide, it is estimated that approximately 19.3 million new cancer cases emerged and about 10 million cancer deaths occurred in $2020 .{ }^{4}$ Lung cancer, colorectal cancer, liver cancer, and breast cancer are considered the main causes of cancer death. ${ }^{4}$ These facts clearly reveal that anti-cancer drug discovery is a rich field of research.

It was found that cancer cells express vascular endothelial growth factor-2 (VEGFR-2) at higher levels than normal cells. Relatively high levels of VEGFR-2 were detected in different cancer types, such as breast, ${ }^{5}$ non-small cell lung, ${ }^{6}$ colorectal, $^{7}$ hepatocellular, ${ }^{8}$ and urothelial ${ }^{9}$ carcinomas. VEGFR-2 is crucial for angiogenesis ${ }^{10-12}$ in order to supply 
cancer cells with oxygen and nutrients, which are required for growth. ${ }^{13,14}$ Accordingly, VEGFR-2 is a significant target in order to develop selective and effective anticancer agents. ${ }^{15-19}$ Many VEGFR-2 inhibitors, such as sorafenib $\mathbf{1},{ }^{20}$ regorafenib $\mathbf{2},{ }^{21}$ sunitinib $\mathbf{3},{ }^{22}$ pazopanib $4,{ }^{23}$ vatalanib $\mathbf{5},{ }^{24}$ and tivozanib $\mathbf{6},{ }^{25}$ are currently FDA approved for treatment of different types of cancers.

According to binding properties, VEGFR-2 inhibitor drugs can be differentiated into two major categories. ${ }^{26}$ Type-I inhibitor drugs such as sunitinib were reported to bind effectively to the active conformation of the receptor. They interact with the region that is normally occupied by the adenine moiety of ATP. ${ }^{25,27}$ In contrast, type-II kinase inhibitor drugs, such as sorafenib, regorafenib, and tivozanib, ${ }^{25}$ were found to bind to a hydrophobic allosteric pocket which is specific to the inactive conformation (DFG-out) of VEGFR-2. ${ }^{28}$ Generally, type-II kinase inhibitors were reported to be more significant than type-I. This is because type-II kinase inhibitors show more specific kinase selectivity and slower off-rates. ${ }^{29}$

On the other hand, VEGFR-2 inhibitor drugs caused some side effects during clinical use. ${ }^{30}$ Hypertension was reported as a major side effect of sorafenib, regorafenib, and tivozanib. ${ }^{31-34}$ Meanwhile, quinoxaline-based compounds have been shown to inhibit VEGFR-2. ${ }^{35}$ Also, the piperazine moiety was incorporated into some potent anticancer compounds, ${ }^{36-38}$ some of which showed VEGFR-2 inhibiting effects. ${ }^{39}$ Moreover, both quinoxaline and piperazine derivatives have been shown to reduce hypertension, ${ }^{40-43}$ and substituted piperazinylquinoxalines have recently been proven to have an antihypertensive effect. ${ }^{44}$

In this study, in line with the reported four pharmacophoric features of type-II VEGFR-2 inhibitor agents ${ }^{25,45-48}$ (Figure 1), and depending on molecular hybridization technique, ${ }^{49,50}$ piperazinylquinoxaline scaffold was used to develop new VEGFR-2 inhibitor candidates as shown in Figure 1. The illustration shows that quinoxaline, which is a hetero aromatic moiety, was designed to occupy the ATP binding domain and show interactions with the key residues Cys919 and/or Glu917. At the same time, a piperazine moiety was incorporated to fill the space between the ATP binding region and the DFG domain. Thirdly, we constructed an amide group to interact by forming hydrogen bonds with the effective residues Glu885 and Asp1046. The amide group played such a role effectively in many potent VEGFR-2 inhibitors, ${ }^{47}$ eg AZD-2932 (see Figure 1). Finally, the terminal hydrophobic moiety was suggested to be substituted phenyl, unsubstituted phenyl, and benzyl. The substituents at the terminal phenyl were selected to be of different steric and electronic properties as well as of different polarity.

\section{Materials and Methods}

\section{Chemistry}

General Method for Synthesis of Final Compounds $\left(10_{\mathrm{a}-\mathrm{g}}\right)$ and II

Equimolar amounts of 2-chloro-3-(piperazin-1-yl)quinoxaline (9), an appropriate intermediate $\left(\mathbf{3}_{\mathbf{a}-\mathbf{g}}\right.$ and $\left.\mathbf{5}\right)$ and $\mathrm{NaHCO}_{3}$ were refluxed in acetonitrile for $2 \mathrm{~h}$. The reaction mixture was cooled and then poured onto water with stirring. The obtained precipitate was collected by filtration, dried, washed with n-hexane and crystallized from ethanol.

4.1.1.1. 2-(4-(3-chloroquinoxalin-2-yl)piperazin-1-yl)- $N$-phenylacetamide $\left(\mathbf{1 0}_{\mathbf{a}}\right)$; white solid (yield 83.25\%); m.p. = $208{ }^{\circ} \mathrm{C} ;{ }^{1} \mathrm{H}$ NMR (DMSO- $\left.d_{6}, 400 \mathrm{MHz}\right) \delta(\mathrm{ppm}): 2.78\left(\mathrm{t}, J=4.4 \mathrm{~Hz}, 4 \mathrm{H}, 2 \mathrm{CH}_{2}\right.$ piperazine), $3.25\left(\mathrm{~s}, 2 \mathrm{H}, \mathrm{CH}_{2} \mathrm{CO}\right), 3.58$ (t, $J=4.4 \mathrm{~Hz}, 4 \mathrm{H}, 2 \mathrm{CH}_{2}$ piperazine), 7.07 (t, $\left.J=7.4 \mathrm{~Hz}, 1 \mathrm{H}, \mathrm{Ar}-\mathrm{H}\right), 7.32(\mathrm{dd}, J=8.1,8.1 \mathrm{~Hz}, 2 \mathrm{H}, \mathrm{Ar}-\mathrm{H}), 7.65$ (m, 3H, Ar-H), 7.75 (ddd, $J=8.3,8.3,1.3 \mathrm{~Hz}, 1 \mathrm{H}$, Ar-H), 7.83 (dd, $J=8.3,0.8 \mathrm{~Hz}, 1 \mathrm{H}, \mathrm{Ar}-\mathrm{H}$ ), 7.89 (dd, $J=8.3,0.9 \mathrm{~Hz}, 1 \mathrm{H}, \mathrm{Ar}-$ $\mathrm{H}), 9.79(\mathrm{~s}, 1 \mathrm{H}, \mathrm{NH})$ (Figure S5 in The supplementary materials) $;{ }^{13} \mathrm{C}$ NMR (DMSO- $\left.d_{6}, 100 \mathrm{MHz}\right) \delta(\mathrm{ppm}): 49.11$, 52.69, 61.99, 120.01, 123.94, 127.16, 127.48, 128.02, 129.13, 131.05, 138.00, 139.02, 139.94, 141.69, 152.76, 168.66 (Figure S6 in The supplementary materials).

4.1.1.2. 2-(4-(3-chloroquinoxalin-2-yl)piperazin-1-yl)- $N$-(4-methoxyphenyl)acetamide $\left(\mathbf{1 0}_{\mathbf{b}}\right)$; white solid (yield 84.32\%); m.p. $=202{ }^{\circ} \mathrm{C} ;{ }^{1} \mathrm{H}$ NMR (DMSO- $\left.d_{6}, 400 \mathrm{MHz}\right) \delta(\mathrm{ppm}): 2.76\left(\mathrm{t}, J=4.6 \mathrm{~Hz}, 4 \mathrm{H}, 2 \mathrm{CH}_{2}\right.$ piperazine), $3.21\left(\mathrm{~s}, 2 \mathrm{H}, \mathrm{CH}_{2} \mathrm{CO}\right), 3.58\left(\mathrm{t}, J=4.4 \mathrm{~Hz}, 4 \mathrm{H}, 2 \mathrm{CH}_{2}\right.$ piperazine), $3.73\left(\mathrm{~s}, 3 \mathrm{H}, \mathrm{CH}_{3}\right), 6.88(\mathrm{~d}, J=9.0 \mathrm{~Hz}, 2 \mathrm{H}, \mathrm{Ar}-\mathrm{H})$, 7.55 (d, $J=9.0 \mathrm{~Hz}, 2 \mathrm{H}, \mathrm{Ar}-\mathrm{H}), 7.63$ (ddd, $J=8.3,8.3,1.3 \mathrm{~Hz}, 1 \mathrm{H}, \mathrm{Ar}-\mathrm{H}), 7.75$ (ddd, $J=8.3,8.3,1.3 \mathrm{~Hz}, 1 \mathrm{H}, \mathrm{Ar}-\mathrm{H}$ ), $7.83(\mathrm{dd}, J=8.2,0.7 \mathrm{~Hz}, 1 \mathrm{H}, \mathrm{Ar}-\mathrm{H}), 7.89(\mathrm{dd}, J=8.2,0.8 \mathrm{~Hz}, 1 \mathrm{H}, \mathrm{Ar}-\mathrm{H}), 9.65(\mathrm{~s}, 1 \mathrm{H}, \mathrm{NH})$ (Figure S7 in The supplementary materials); ${ }^{13} \mathrm{C}$ NMR (DMSO- $\left.d_{6}, 100 \mathrm{MHz}\right) \delta(\mathrm{ppm}): 49.11,52.73,55.64,61.97,114.23,121.62$, 


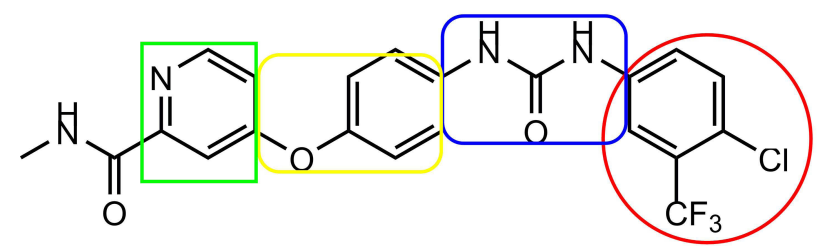

Sorafenib 4

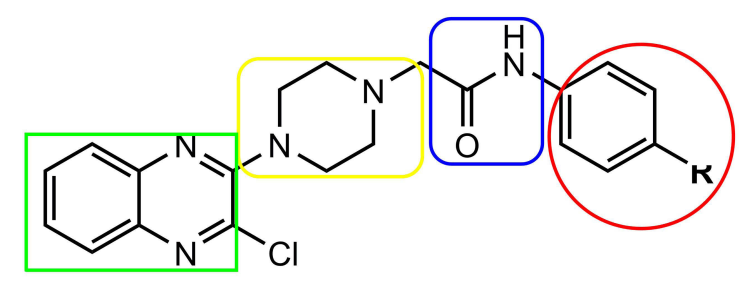

$10_{\mathrm{a}-\mathrm{g}}$

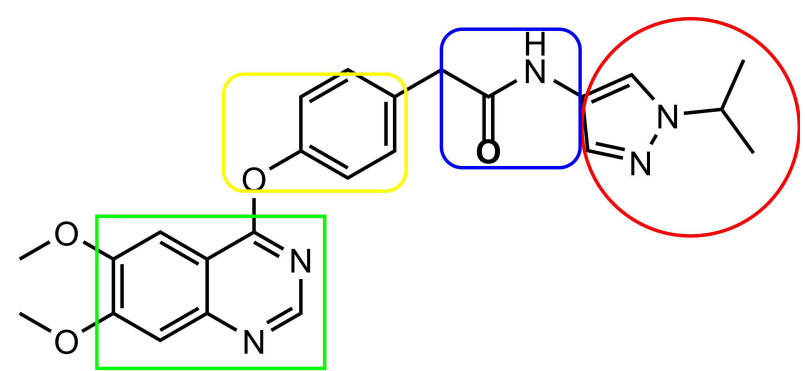

AZD-2932 7

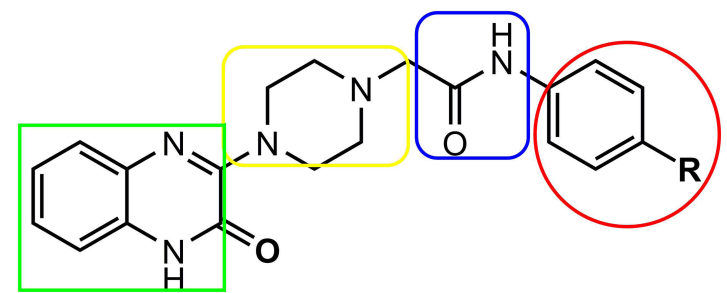

$13 \mathrm{a-g}$

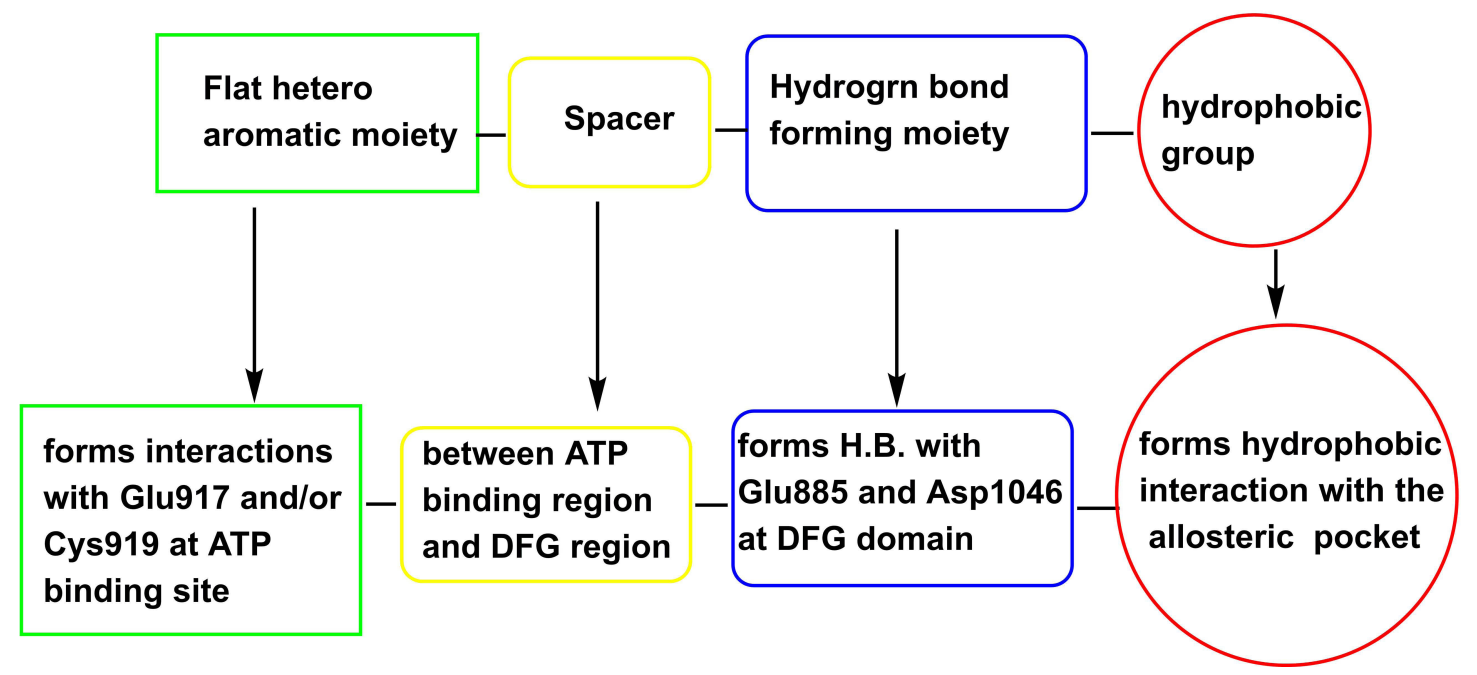

Figure I VEGFR-2 inhibitors (type II) pharmacophoric features as presented in sorafenib, AZD-2932, and the new derivatives and their corresponding binding regions as well.

$127.17,127.85,128.02,131.05,132.21,138.01,139.96,141.71,152.79,155.83,168.13$ (Figure S8 in The supple mentary materials).

4.1.1.3. $\quad N$-(4-chlorophenyl)-2-(4-(3-chloroquinoxalin-2-yl)piperazin-1-yl)acetamide $\quad\left(\mathbf{1 0}_{\mathbf{c}}\right) ; \quad$ White solid (yield $81.75 \%$ ); m.p. $=232{ }^{\circ} \mathrm{C} ;{ }^{1} \mathrm{H}$ NMR (DMSO- $\left.d_{6}, 400 \mathrm{MHz}\right) \delta(\mathrm{ppm}): 2.77$ (t, $J=4.5 \mathrm{~Hz}, 4 \mathrm{H}, 2 \mathrm{CH}_{2}$ piperazine), 3.25 (s, $2 \mathrm{H}$, $\mathrm{CH}_{2} \mathrm{CO}$ ), 3.58 (t, $J=4.5 \mathrm{~Hz}, 4 \mathrm{H}, 2 \mathrm{CH}_{2}$ piperazine), 7.36 (d, $\left.J=8.9 \mathrm{~Hz}, 2 \mathrm{H}, \mathrm{Ar}-\mathrm{H}\right), 7.63$ (ddd, $J=8.3,7.0,1.3 \mathrm{~Hz}, 1 \mathrm{H}$, Ar-H), 7.70 (d, $J=8.9 \mathrm{~Hz}, 2 \mathrm{H}$, Ar-H), 7.75 (ddd, $J=8.2,8.2,1.3 \mathrm{~Hz}, 1 \mathrm{H}, \mathrm{Ar}-\mathrm{H}), 7.83$ (dd, $J=8.2,0.7 \mathrm{~Hz}, 1 \mathrm{H}, \mathrm{Ar}-\mathrm{H}$ ), $7.89(\mathrm{dd}, J=8.2,0.8 \mathrm{~Hz}, 1 \mathrm{H}, \mathrm{Ar}-\mathrm{H}), 9.94(\mathrm{~s}, 1 \mathrm{H}, \mathrm{NH})$ (Figure S9 in The supplementary materials) ${ }^{13} \mathrm{C}$ NMR (DMSO- $d_{6}$, $100 \mathrm{MHz}) \delta(\mathrm{ppm}): 49.05,52.66,61.92,121.65,127.15,127.54,127.82,128.04,129.01,131.07,137.98,139.93,141.68$, $152.75,168.94$ (Figure S10 in The supplementary materials).

4.1.1.4. 2-(4-(3-chloroquinoxalin-2-yl)piperazin-1-yl)- $N$-(4-fluorophenyl)acetamide $\quad\left(\mathbf{1 0}_{\mathbf{d}}\right) ; \quad$ gray $\quad$ solid $\quad$ (yield 80.65\%); m.p. $=195{ }^{\circ} \mathrm{C} ;{ }^{1} \mathrm{H}$ NMR (DMSO- $\left.d_{6}, 400 \mathrm{MHz}\right) \delta(\mathrm{ppm}): 2.76\left(\mathrm{t}, J=4.4 \mathrm{~Hz}, 4 \mathrm{H}, 2 \mathrm{CH}_{2}\right.$ piperazine), 3.24 (s, $2 \mathrm{H}$, $\mathrm{CH}_{2} \mathrm{CO}$ ), 3.58 (t, $J=4.3 \mathrm{~Hz}, 4 \mathrm{H}, 2 \mathrm{CH}_{2}$ piperazine), 7.16 (dd, $\left.J=8.9 \mathrm{~Hz}, 2 \mathrm{H}, \mathrm{Ar}-\mathrm{H}\right), 7.64$ (ddd, $J=8.2,7.0,1.2 \mathrm{~Hz}, 1 \mathrm{H}$, 
Ar-H), 7.68 (dd, $J=9.0,5.0 \mathrm{~Hz}, 2 \mathrm{H}, \mathrm{Ar}-\mathrm{H}), 7.75$ (ddd, $J=8.3,8.3,1.3 \mathrm{~Hz}, 1 \mathrm{H}, \mathrm{Ar}-\mathrm{H}), 7.83$ (dd, $J=8.2,0.6 \mathrm{~Hz}, 1 \mathrm{H}, \mathrm{Ar}-$ $\mathrm{H}), 7.89(\mathrm{dd}, J=8.2,0.8 \mathrm{~Hz}, 1 \mathrm{H}, \mathrm{Ar}-\mathrm{H}), 9.86(\mathrm{~s}, 1 \mathrm{H}, \mathrm{NH})$ (Figure S11 in The supplementary materials) ${ }^{13} \mathrm{C}$ NMR $\left(\right.$ DMSO- $\left.d_{6}, 100 \mathrm{MHz}\right) \delta(\mathrm{ppm}): 49.07,52.69,61.92,115.55,115.77,121.88,127.16,127.84,128.04,131.07,135.42$, $137.99,139.94,141.70,152.77,168.65$ (Figure S12 in The supplementary materials).

4.1.1.5. 2-(4-(3-chloroquinoxalin-2-yl)piperazin-1-yl)- $N$-(p-tolyl)acetamide $\left(\mathbf{1 0}_{\mathbf{e}}\right)$; white solid (yield 84.35\%); m.p. = $215^{\circ} \mathrm{C} ;{ }^{1} \mathrm{H}$ NMR (DMSO- $\left.d_{6}, 400 \mathrm{MHz}\right) \delta(\mathrm{ppm}): 2.26\left(\mathrm{~s}, 3 \mathrm{H}, \mathrm{CH}_{3}\right), 2.76\left(\mathrm{t}, J=4.5 \mathrm{~Hz}, 4 \mathrm{H}, 2 \mathrm{CH}_{2}\right.$ piperazine), $3.22(\mathrm{~s}$, $2 \mathrm{H}, \mathrm{CH}_{2} \mathrm{CO}$ ), 3.58 (t, $J=4.3 \mathrm{~Hz}, 4 \mathrm{H}, 2 \mathrm{CH}_{2}$ piperazine), 7.11 (d, $\left.J=8.3 \mathrm{~Hz}, 2 \mathrm{H}, \mathrm{Ar}-\mathrm{H}\right), 7.53$ (d, $\left.J=8.3 \mathrm{~Hz}, 2 \mathrm{H}, \mathrm{Ar}-\mathrm{H}\right)$, 7.64 (ddd, $J=8.2,7.0,1.2 \mathrm{~Hz}, 1 \mathrm{H}, \mathrm{Ar}-\mathrm{H}$ ), 7.75 (ddd, $J=8.2,8.2,1.2 \mathrm{~Hz}, 1 \mathrm{H}$, Ar-H), 7.83 (d, $J=7.7 \mathrm{~Hz}, 1 \mathrm{H}$, Ar-H), 7.89 $(\mathrm{d}, J=7.6 \mathrm{~Hz}, 1 \mathrm{H}, \mathrm{Ar}-\mathrm{H}), 9.70$ (s, $1 \mathrm{H}, \mathrm{NH})$ (Figure S13 in The supplementary materials); ${ }^{13} \mathrm{C}$ NMR (DMSO- $d_{6}, 100$ MHz) $\delta$ (ppm): 20.89, 49.08, 52.68, 61.94, 120.05, 127.14, 127.82, 128.04, 129.51, 131.07, 132.93, 136.45, 137.97, 139.92, 141.69, 152.75, 168.47 (Figure S14 in The supplementary materials).

4.1.1.6. $\quad \mathrm{N}$-(4-acetylphenyl)-2-(4-(3-chloroquinoxalin-2-yl)piperazin-1-yl)acetamide $\quad\left(\mathbf{1 0}_{\mathbf{f}}\right)$; white $\quad$ solid (yield 77.45\%); m.p. $=210{ }^{\circ} \mathrm{C} ;{ }^{1} \mathrm{H}$ NMR (DMSO- $\left.d_{6}, 400 \mathrm{MHz}\right) \delta(\mathrm{ppm}): 2.54\left(\mathrm{~s}, 3 \mathrm{H}, \mathrm{CH}_{3}\right), 2.78$ (t, $J=4.4 \mathrm{~Hz}, 4 \mathrm{H}, 2 \mathrm{CH}_{2}$ piperazine), 3.30 (s, $2 \mathrm{H}, \mathrm{CH}_{2} \mathrm{CO}$ ), 3.58 (t, $J=4.4 \mathrm{~Hz}, 4 \mathrm{H}, 2 \mathrm{CH}_{2}$ piperazine), 7.63 (ddd, $J=8.2,7.0,1.2 \mathrm{~Hz}, 1 \mathrm{H}, \mathrm{Ar}-\mathrm{H}$ ), 7.75 (ddd, $J=8.3,8.3,1.2 \mathrm{~Hz}, 1 \mathrm{H}, \mathrm{Ar}-\mathrm{H}), 7.83$ (3, 3H, Ar-H), 7.89 (dd, $J=8.2,0.7 \mathrm{~Hz}, 1 \mathrm{H}, \mathrm{Ar}-\mathrm{H}), 7.93$ (d, $J=8.7 \mathrm{~Hz}$, $2 \mathrm{H}, \mathrm{Ar}-\mathrm{H}), 10.15(\mathrm{~s}, 1 \mathrm{H}, \mathrm{NH})$ (Figure S15 in The supplementary materials) $;{ }^{13} \mathrm{C}$ NMR (DMSO- $\left.d_{6}, 100 \mathrm{MHz}\right) \delta(\mathrm{ppm})$ : 26.90, 49.08, 52.64, 61.96, 119.20, 127.15, 127.83, 128.02, 129.85, 131.04, 132.35, 137.99, 139.93, 141.68, 143.39, 152.75, 169.37, 197.09 (Figure S16 in The supplementary materials).

4.1.1.7. 2-(4-(3-chloroquinoxalin-2-yl)piperazin-1-yl)- $N$-(4-nitrophenyl)acetamide $\left(\mathbf{1 0}_{\mathbf{g}}\right)$; yellowish solid (yield 75.35\%); m.p. $=228{ }^{\circ} \mathrm{C} ;{ }^{1} \mathrm{H}$ NMR (DMSO- $\left.d_{6}, 400 \mathrm{MHz}\right) \delta(\mathrm{ppm}): 2.78\left(\mathrm{t}, J=4.5 \mathrm{~Hz}, 4 \mathrm{H}, 2 \mathrm{CH}_{2}\right.$ piperazine), $3.27(\mathrm{~s}, 2 \mathrm{H}$, $\mathrm{CH}_{2} \mathrm{CO}$ ), 3.58 (t, $J=4.5 \mathrm{~Hz}, 4 \mathrm{H}, 2 \mathrm{CH}_{2}$ piperazine), 7.64 (ddd, $J=8.2,7.2,1.2 \mathrm{~Hz}, 1 \mathrm{H}, \mathrm{Ar}-\mathrm{H}$ ), 7.75 (ddd, $J=8.3,8.3,1.3$ $H z, 1 \mathrm{H}, \mathrm{Ar}-\mathrm{H}), 7.83$ (dd, $J=8.3,0.8 \mathrm{~Hz}, 1 \mathrm{H}, \mathrm{Ar}-\mathrm{H}), 7.89$ (dd, $J=8.2 .0 .8 \mathrm{~Hz}, 1 \mathrm{H}, \mathrm{Ar}-\mathrm{H}), 7.93(\mathrm{~d}, J=9.2 \mathrm{~Hz}, 2 \mathrm{H}, \mathrm{Ar}-\mathrm{H})$, $8.23(\mathrm{~d}, J=9.2 \mathrm{~Hz}, 2 \mathrm{H}, \mathrm{Ar}-\mathrm{H}), 10.42(\mathrm{~s}, 1 \mathrm{H}, \mathrm{NH})$ (Figure S17 and Figure S18 in The supplementary materials); ${ }^{13} \mathrm{C}$ NMR (DMSO- $\left.d_{6}, 100 \mathrm{MHz}\right) \delta$ (ppm): 49.04, 52.60, 61.92, 119.65, 125.30, 127.14, 127.81, 128.02, 131.04, 137.97, 139.91, 141.66, 142.80, 145.23, 152.71, 169.83 (Figure S19 in The supplementary materials).

4.1.1.8. $N$-benzyl-2-(4-(3-chloroquinoxalin-2-yl)piperazin-1-yl)acetamide (11); white solid (yield 81.15\%); m.p. = $205{ }^{\circ} \mathrm{C} ;{ }^{1} \mathrm{H}$ NMR (DMSO- $\left.d_{6}, 400 \mathrm{MHz}\right) \delta(\mathrm{ppm}): 2.69$ (t, $J=4.6 \mathrm{~Hz}, 4 \mathrm{H}, 2 \mathrm{CH}_{2}$ piperazine), $3.10\left(\mathrm{~s}, 2 \mathrm{H}, \mathrm{CH}_{2} \mathrm{CO}\right), 3.54$ (t, $J=4.5 \mathrm{~Hz}, 4 \mathrm{H}, 2 \mathrm{CH}_{2}$ piperazine), 4.33 (d, $J=6.2 \mathrm{~Hz}, 2 \mathrm{H}, \mathrm{CH}_{2} \mathrm{NH}$ ), 7.22-7.35 (m, 5H, Ar-H), 7.63 (ddd, $J=8.2,7.0$, $1.2 \mathrm{~Hz}, 1 \mathrm{H}, \mathrm{Ar}-\mathrm{H}$ ), 7.75 (ddd, $J=8.3,8.3,1.3 \mathrm{~Hz}, 1 \mathrm{H}, \mathrm{Ar}-\mathrm{H}), 7.82$ (dd, $J=8.2,0.8 \mathrm{~Hz}, 1 \mathrm{H}, \mathrm{Ar}-\mathrm{H}), 7.88$ (dd, $J=8.2,0.9$ $H z, 1 \mathrm{H}, \mathrm{Ar}-\mathrm{H}$ ), 8.39 (t, $J=6.2 \mathrm{~Hz}, 1 \mathrm{H}, \mathrm{NH}$ ) (Figure S20 in The supplementary materials); ${ }^{13} \mathrm{C}$ NMR (DMSO- $d_{6}, 100$ MHz) $\delta(\mathrm{ppm}): 42.36,49.07,52.85,61.48,127.15,127.19,127.63,127.82,128.04,128.74,131.05,137.98,139.93$, $140.12,141.69,152.76,169.82$ (Figure S21 in The supplementary materials); Mass $(\mathrm{m} / \mathrm{z}): 397.59\left(\mathrm{M}^{+}+2,13.64 \%\right)$, $395.56\left(\mathrm{M}^{+}, 34.12 \%\right), 388.96,387.93,386.12,344.32$, 314.20, 308.45, 398.22, 379.17, 377.97, 373.08, 365.60, 349.06, 286.33, 283.27, 274.38, 273.60, 265.28, 260.63, 246.46, 207.83, 201.13, 144.25, 105.18, 75.45, 69.43 (100\%, base peak) (Figure S22 in The supplementary materials); Anal. Calcd. for $\mathrm{C}_{21} \mathrm{H}_{22} \mathrm{ClN}_{5} \mathrm{O}: \mathrm{C}, 63.71 ; \mathrm{H}, 5.60 ; \mathrm{N}, 17.69$. Found: $\mathrm{C}$, 63.98; H, 5.72; N, 17.85\%.

4.1.2. General method for synthesis of final compounds $\left(\mathbf{1 3}_{\mathrm{a}-\mathrm{g}}\right)$ and $\mathbf{1 4}$ : Equimolar amounts of 3-(piperazin-1-yl) quinoxalin-2(1H)-one (12), an appropriate intermediate $\left(\mathbf{3}_{\mathbf{a}-\mathrm{g}}\right.$ and $\left.\mathbf{5}\right)$ and $\mathrm{NaHCO}_{3}$ were heated under reflux in acetonitrile for $2 \mathrm{~h}$. The reaction mixture was then cooled, poured onto cold water and stirred for half an hour. The obtained precipitate was collected by filtration, dried, washed with n-hexane and crystallized from ethanol.

4.1.2.1. 2-(4-(3-oxo-3,4-dihydroquinoxalin-2-yl)piperazin-1-yl)- $N$-phenylacetamide $\quad\left(\mathbf{1 3}_{\mathbf{a}}\right)$; white solid (yield 74.65\%); m.p. $=243{ }^{\circ} \mathrm{C} ;{ }^{1} \mathrm{H}$ NMR (DMSO- $\left.d_{6}, 400 \mathrm{MHz}\right) \delta(\mathrm{ppm}): 2.66\left(\mathrm{t}, J=4.8 \mathrm{~Hz}, 4 \mathrm{H}, 2 \mathrm{CH}_{2}\right.$ piperazine), 3.19 (s, $2 \mathrm{H}$, $\mathrm{CH}_{2} \mathrm{CO}$ ), 3.96 (t, $J=4.8 \mathrm{~Hz}, 4 \mathrm{H}, 2 \mathrm{CH}_{2}$ piperazine), 7.06 (t, $\left.J=7.4 \mathrm{~Hz}, 1 \mathrm{H}, \mathrm{Ar}-\mathrm{H}\right), 7.11-7.18$ (m, 3H, Ar-H), 7.31 (dd, $J=8.2,8.2 \mathrm{~Hz}, 2 \mathrm{H}, \mathrm{Ar}-\mathrm{H}), 7.38$ (d, $J=7.4 \mathrm{~Hz}, 1 \mathrm{H}, \mathrm{Ar}-\mathrm{H}), 7.64$ (d, $J=7.7 \mathrm{~Hz}, 2 \mathrm{H}, \mathrm{Ar}-\mathrm{H}), 9.80$ (s, 1H, NHCO), 12.21 (s, $1 \mathrm{H}, \mathrm{NH}$ quinoxaline) (Figure S23 in The supplementary materials); ${ }^{13} \mathrm{C}$ NMR (DMSO- $\left.d_{6}, 100 \mathrm{MHz}\right) \delta(\mathrm{ppm}): 46.52$, $53.10,62.05,114.89,120.03,123.65,123.96,125.18,125.56,129.14,129.79,132.71,138.99,151.61,152.53,168.72$ (Figure S24 in The supplementary materials). 
4.1.2.2. $N$-(4-methoxyphenyl)-2-(4-(3-oxo-3,4-dihydroquinoxalin-2-yl)piperazin-1-yl)acetamide (13 $\mathbf{b})$; white solid (yield 73.23\%); m.p. $=235{ }^{\circ} \mathrm{C} ;{ }^{1} \mathrm{H}$ NMR (DMSO- $\left.d_{6}, 400 \mathrm{MHz}\right) \delta(\mathrm{ppm}): 2.66\left(\mathrm{~s}, 4 \mathrm{H}, 2 \mathrm{CH}_{2}\right.$ piperazine), 3.12 (s, $2 \mathrm{H}$, $\mathrm{CH}_{2} \mathrm{CO}$ ), 3.72 (s, $\left.3 \mathrm{H}, \mathrm{OCH}_{3}\right), 3.96$ (s, 4H, 2CH $\mathrm{CH}_{2}$ piperazine), 6.88 (d, J=8.6 Hz, 2H, Ar-H), 7.14-7.17 (m, 3H, Ar-H), 7.39 (d, $J=7.3 \mathrm{~Hz}, 1 \mathrm{H}, \mathrm{Ar}-\mathrm{H}), 7.54$ (d, $J=8.6 \mathrm{~Hz}, 2 \mathrm{H}, \mathrm{Ar}-\mathrm{H}), 9.63$ (s, 1H, NHCO), 12.13 (s, 1H, NH quinoxaline) (Figure S25 in The supplementary materials); ${ }^{13} \mathrm{C}$ NMR (DMSO- $\left.d_{6}, 100 \mathrm{MHz}\right) \delta(\mathrm{ppm}): 46.50,53.11,55.63,61.97$, 114.24, 114.84, 121.76, 123.72, 125.21, 125.56, 129.66, 132.03, 132.69, 151.58, 152.50, 155.89, 168.30 (Figure S26 in The supplementary materials).

4.1.2.3. $N$-(4-chlorophenyl)-2-(4-(3-oxo-3,4-dihydroquinoxalin-2-yl)piperazin-1-yl)acetamide $\quad\left(\mathbf{1 3}_{\mathbf{c}}\right)$; white solid

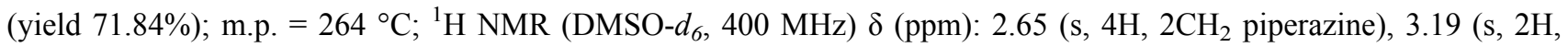
$\mathrm{CH}_{2} \mathrm{CO}$ ), 3.96 (s, 4H, 2CH 2 piperazine), 7.12-7.17 (m, 3H, Ar-H), 7.36-740 (m, 3H, Ar-H), 7.68 (d, $J=8.8 \mathrm{~Hz}, 2 \mathrm{H}, \mathrm{Ar}-$ $\mathrm{H}), 9.92(\mathrm{~s}, 1 \mathrm{H}, \mathrm{NHCO}), 12.12\left(\mathrm{~s}, 1 \mathrm{H}, \mathrm{NH}\right.$ quinoxaline) (Figure S27 in The supplementary materials); ${ }^{13} \mathrm{C}$ NMR $\left(\right.$ DMSO- $\left._{6}, 100 \mathrm{MHz}\right) \delta(\mathrm{ppm}): 46.48,53.10,62.03,114.83,121.61,123.64,125.17,125.57,127.48,129.00,129.74$, 132.70, 138.01, 151.59, 152.49, 168.88 (Figure S28 in The supplementary materials).

4.1.2.4. $\quad N$-(4-fluorophenyl)-2-(4-(3-oxo-3,4-dihydroquinoxalin-2-yl)piperazin-1-yl)acetamide $\left(\mathbf{1 3}_{\mathbf{d}}\right)$; brown solid (yield 72.49\%); m.p. $=227{ }^{\circ} \mathrm{C} ;{ }^{1} \mathrm{H}$ NMR (DMSO- $\left.d_{6}, 400 \mathrm{MHz}\right) \delta(\mathrm{ppm}): 2.66$ (s, 4H, 2 $\mathrm{CH}_{2}$ piperazine), 3.18 (s, $2 \mathrm{H}$, $\mathrm{CH}_{2} \mathrm{CO}$ ), 3.96 (s, 4H, 2CH 2 piperazine), 7.13-7.17 (m, 5H, Ar-H), 7.39 (d, $\left.J=7.4 \mathrm{~Hz}, 1 \mathrm{H}, \mathrm{Ar}-\mathrm{H}\right), 7.67$ (dd, $J=8.8,5.0$ $\mathrm{Hz}, 2 \mathrm{H}, \mathrm{Ar}-\mathrm{H}), 9.84$ (s, 1H, NHCO), 12.12 (s, 1H, NH quinoxaline) (Figure S29 in The supplementary materials); ${ }^{13} \mathrm{C}$ NMR (DMSO- $\left.d_{6}, 100 \mathrm{MHz}\right) \delta(\mathrm{ppm}): 46.48,53.12,62.00,114.83,115.54,115.76,121.93,123.63,125.16,125.57$, $129.47,132.71,135.42,151.59,152.49,168.59$ (Figure S30 in The supplementary materials).

4.1.2.5. 2-(4-(3-oxo-3,4-dihydroquinoxalin-2-yl)piperazin-1-yl)- $N$-(p-tolyl)acetamide $\quad\left(\mathbf{1 3}_{\mathbf{e}}\right)$; white solid (yield 73.56\%); m.p. $=248{ }^{\circ} \mathrm{C} ;{ }^{1} \mathrm{H}$ NMR (DMSO- $\left.d_{6}, 400 \mathrm{MHz}\right) \delta(\mathrm{ppm}): 2.26\left(\mathrm{~s}, 3 \mathrm{H}, \mathrm{CH}_{3}\right), 2.66\left(\mathrm{~s}, 4 \mathrm{H}, 2 \mathrm{CH}_{2}\right.$ piperazine), 3.17 (s, 2H, $\mathrm{CH}_{2} \mathrm{CO}$ ), 3.96 (s, 4H, 2 $\mathrm{CH}_{2}$ piperazine), 7.11-7.17 (m, 5H, Ar-H), 7.39 (d, J= 7.4 Hz, 1H, Ar-H), 7.52 (d, $J=8.4 \mathrm{~Hz}, 2 \mathrm{H}, \mathrm{Ar}-\mathrm{H}), 9.68(\mathrm{~s}, 1 \mathrm{H}, \mathrm{NHCO}), 12.13(\mathrm{~s}, 1 \mathrm{H}, \mathrm{NH}$ quinoxaline) (Figure S31 in The supplementary materials); ${ }^{13} \mathrm{C}$ NMR (DMSO- $\left.d_{6}, 100 \mathrm{MHz}\right) \delta(\mathrm{ppm}): 20.91,46.49,53.13,62.02,114.83,120.00,123.61,125.16,125.57,129.49$, 129.77, 132.71, 132.82, 136.54, 151.59, 152.49, 168.31 (Figure S32 in The supplementary materials).

4.1.2.6. $\mathrm{N}$-(4-acetylphenyl)-2-(4-(3-oxo-3,4-dihydroquinoxalin-2-yl)piperazin-1-yl)acetamide ( $\left.\mathbf{1 3}_{\mathrm{f}}\right)$; brownish solid (yield 68.50\%); m.p. $=239{ }^{\circ} \mathrm{C} ;{ }^{1} \mathrm{H}$ NMR $\left(\mathrm{DMSO}_{6}, 400 \mathrm{MHz}\right) \delta(\mathrm{ppm}): 2.53\left(\mathrm{~s}, 3 \mathrm{H}, \mathrm{CH}_{3}\right), 2.67\left(\mathrm{~s}, 4 \mathrm{H}, 2 \mathrm{CH}_{2}\right.$ piperazine), 3.24 (s, $\left.2 \mathrm{H}, \mathrm{CH}_{2} \mathrm{CO}\right), 3.96\left(\mathrm{~s}, 4 \mathrm{H}, 2 \mathrm{CH}_{2}\right.$ piperazine), $7.13-7.17$ (m, 3H, Ar-H quinoxaline), 7.39 (d, $J=7.4$ $H z, 1 \mathrm{H}, \mathrm{Ar}-\mathrm{H}$ ), 7.80 (d, $J=8.7 \mathrm{~Hz}, 2 \mathrm{H}, \mathrm{Ar}-\mathrm{H}), 7.93$ (d, $J=8.7 \mathrm{~Hz}, 2 \mathrm{H}, \mathrm{Ar}-\mathrm{H}), 10.12$ (s, 1H, NHCO), 12.13 (s, 1H, NH quinoxaline) (Figure S33 in The supplementary materials); ${ }^{13} \mathrm{C}$ NMR (DMSO- $\left.d_{6}, 100 \mathrm{MHz}\right) \delta(\mathrm{ppm}): 26.89,46.50$, 53.05, 62.03, 114.84, 119.22, 123.69, 125.21, 125.57, 129.71, 129.86, 132.35, 132.69, 143.37, 151.59, 152.49, 169.40, 197.18 (Figure S34 in The supplementary materials).

4.1.2.7. $N$-(4-nitrophenyl)-2-(4-(3-oxo-3,4-dihydroquinoxalin-2-yl)piperazin-1-yl)acetamide $\left(\mathbf{1 3}_{\mathbf{g}}\right)$; yellowish solid (yield 65.30\%); m.p. $=256{ }^{\circ} \mathrm{C} ;{ }^{1} \mathrm{H}$ NMR (DMSO- $\left.d_{6}, 400 \mathrm{MHz}\right) \delta(\mathrm{ppm}): 2.67$ (s, 4H, 2 $\mathrm{CH}_{2}$ piperazine), 3.27 (s, $2 \mathrm{H}$, $\mathrm{CH}_{2} \mathrm{CO}$ ), 3.96 (s, 4H, 2CH 2 piperazine), 7.12-7.17 (m, 3H, Ar-H quinoxaline), 7.38 (d, J= $\left.7.4 \mathrm{~Hz}, 1 \mathrm{H}, \mathrm{Ar}-\mathrm{H}\right), 7.92$ (d, $J=9.1 \mathrm{~Hz}, 2 \mathrm{H}, \mathrm{Ar}-\mathrm{H}), 8.22(\mathrm{~d}, J=9.1 \mathrm{~Hz}, 2 \mathrm{H}, \mathrm{Ar}-\mathrm{H}), 10.42(\mathrm{~s}, 1 \mathrm{H}, \mathrm{NHCO}), 12.12$ (s, 1H, NH quinoxaline) (Figure S35 in The supplementary materials); ${ }^{13} \mathrm{C}$ NMR (DMSO- $\left.d_{6}, 100 \mathrm{MHz}\right) \delta(\mathrm{ppm}): 44.37,50.93,59.95,112.75,117.52,121.49$, $123.04,123.20,123.45,127.68,130.60,140.66,143.18,149.47,150.40,167.70$ (Figure S36 in The supplementary $\underline{\text { materials). }}$.

4.1.2.8. $\quad N$-benzyl-2-(4-(3-oxo-3,4-dihydroquinoxalin-2-yl)piperazin-1-yl)acetamide (14); white solid (yield 74.60\%); m.p. $=230{ }^{\circ} \mathrm{C} ;{ }^{1} \mathrm{H}$ NMR (DMSO- $\left.d_{6}, 400 \mathrm{MHz}\right) \delta(\mathrm{ppm}): 2.59$ (t, $J=4.5 \mathrm{~Hz}, 4 \mathrm{H}, 2 \mathrm{CH}_{2}$ piperazine), 3.04 (s, $2 \mathrm{H}$, $\mathrm{CH}_{2} \mathrm{CO}$ ), 3.93 (s, $4 \mathrm{H}, 2 \mathrm{CH}_{2}$ piperazine), 4.32 (d, $J=6.2 \mathrm{~Hz}, 2 \mathrm{H}, \mathrm{CH}_{2} \mathrm{NH}$ ), 7.12-7.17 (m, 3H, Ar-H quinoxaline), 7.227.35 (m, 5H, Ar-H), 7.38 (d, $J=7.3 \mathrm{~Hz}, 1 \mathrm{H}, \mathrm{Ar}-\mathrm{H}), 8.36$ (s, 1H, NHCO), 12.12 (s, 1H, NH quinoxaline) (Figure S37 in The supplementary materials); ${ }^{13} \mathrm{C}$ NMR (DMSO- $\left.d_{6}, 100 \mathrm{MHz}\right) \delta(\mathrm{ppm}): 42.35,46.47,53.24,61.51,114.83,123.69$, 125.20, 125.56, 127.20, 127.62, 128.74, 129.68, 132.69, 140.07, 151.56, 152.49, 169.88 (Figure S38 in The supplemen tary materials). 


\section{Biological Testing} In vitro Antitumor Assay

This assay was performed against four human cancer cell lines, namely, A549, HepG-2, Caco-2, and MDA. In line with the MTT protocol ${ }^{60}$ we carried out this colorimetric assay with quantitative measurement of the antitumor activity. The assay is primarily based on a biochemical reaction in which mitochondrial succinate dehydrogenase in viable cells converts the yellow tetrazolium bromide (MTT) to a purple formazan derivative. In general, the cells were cultured in RPMI-1640 medium with $10 \%$ fetal bovine serum. Penicillin $(100$ units $/ \mathrm{mL})$ and streptomycin $(100 \mu \mathrm{g} / \mathrm{mL})$ were added in a $5 \% \mathrm{CO}_{2}$ incubator at $37{ }^{\circ} \mathrm{C}$. Seeding of the cells was in a 96 -well plate at $37 \mathrm{C}$ for $48 \mathrm{~h}$ under $5 \% \mathrm{CO}_{2}$ and it was at a density of $1.0 \times 10^{4}$ cells $/$ well. After the initial incubation, the cells were treated with the new derivatives at different concentrations and incubated for $24 \mathrm{~h}$. Then we add $20 \mu \mathrm{L}$ of MTT in a solution of $5 \mathrm{mg} / \mathrm{mL}$ concentration and incubate for $4 \mathrm{~h}$. To dissolve the obtained purple formazan, $100 \mu \mathrm{L}$ of DMSO was added into each well. Measuring and recording the colorimetric assay were carried out by a plate reader (EXL 800, USA) at an absorbance of $570 \mathrm{~nm}$. The percentage of relative cell viability was calculated.

\section{VEGFR-2 (KDR) Kinase Assay}

According to the manufacturer's instructions, the VEGFR-2 Kinase Assay Kit (BPS-Bioscience, USA) was used for testing the VEGFR tyrosine kinase activity according to. In brief, the diluted VEGFR-2 enzyme or tested compound (at different dilution of $1000,300,100,30,10,3,1$, and $0.30 \mathrm{nM}$ ) was added to the wells of a 96-well plate, and the reaction mixture was incubated at $30{ }^{\circ} \mathrm{C}$ for $30 \mathrm{~min}$, then $25 \mathrm{~mL}$ of ADP-GloTM Reagent was added. The reaction plate was incubated at RT for $45 \mathrm{~min}$, and the kinase detection reagent (Kinase-Glo MAX (Promega)) was added. A luminescence signal was detected and quantified by a BioTek Synergy 2 microplate reader for determination of $\mathrm{IC}_{50}$ of the tested compounds. A blank control was set up to which an equal volume of kinase assay buffer was added instead of the tested compounds. The activity for each protein kinase target was corrected by subtracting the blank control value.

\section{Cell Cycle Analysis}

This assay was conducted according to the reported method. ${ }^{61}$ In short, HepG-2 cells were seeded into six-well plates (2 $\times 10^{5}$ cells per each well) and incubated for $24 \mathrm{~h}$ at $37{ }^{\circ} \mathrm{C}$ and $5 \% \mathrm{CO}_{2}$. After that, they were treated with $9.52 \mu \mathrm{M}$ of compound 11 dissolved in DMSO (1\% v/v) for $48 \mathrm{~h}$. After the cells were washed several times with cold phosphate buffered saline (PBS), fixed with ethyl alcohol (70\%) and rinsed again with PBS, they were stained with the DNA fluorochrome propidium iodide and kept at $37{ }^{\circ} \mathrm{C}$ for $15 \mathrm{~min}$ in the dark. The cell distribution was analyzed using Epics XL-MCL ${ }^{\text {тм }}$ Flow Cytometer (Beckman Coulter), and the data were analyzed using Flowing software (version 2.5.1, Turku Centre for Biotechnology, Turku, Finland).

\section{Apoptosis Assay}

Apoptosis detection was carried out using Annexin V fluorescein isothiocyanate (V-FITC)/PI kit according to the reported procedure. ${ }^{62}$ HepG-2 cells were seeded and incubated for $24 \mathrm{~h}$, then treated with $(9.52 \mu \mathrm{M})$ of compound $\mathbf{1 1}$ for $28 \mathrm{~h}$. The cells were then collected, washed 3 times with PBS, fixed with ice-cold absolute ethanol (70\%) and stained with Annexin-V-FITC/propidium iodide (PI) using a double staining kit for $20 \mathrm{~min}$ in the dark. Epics XL-MCL ${ }^{\text {TM }}$ Flow Cytometer was used to evaluate the apoptosis.

\section{Western Blot Analysis}

In line with the manufacturer's instructions, ${ }^{63}$ Western blot analysis was carried out for evaluation of the apoptotic effect of compound 11 (at its $\mathrm{IC}_{50}$ ) on the proteins; BAX, Bcl-2, caspase-3 and p53 in HepG-2 cells. The cells were treated with compound 11 or DMSO (as control), lysed in cold lysis buffer $(250 \mu \mathrm{L})$ containing Tris-Base [10 mM], ethylenediaminetetraacetic acid [25 mM], ethylene glycol bis (2-aminoethyl) $1 \%$ [v/v] NP-40, tetraacetic acid [EGTA, $25 \mathrm{mM}$ ], NaCl [100 $\mathrm{mM}], 1 \%[\mathrm{v} / \mathrm{v}]$ Triton X-100, and directly supplemented with 1:400 protease and phosphatase inhibitors mixture (Sigma) while $\mathrm{pH}$ was kept at 7.4. Additional lysis of the cancer cells was achieved by freezing for 1.5 hours at $-80^{\circ} \mathrm{C}$. The cells were then thawed, collected, sonicated, and centrifuged. The total protein concentration was measured using the Pierce $660 \mathrm{~nm}$ Protein Assay Reagent (Thermo Fisher Scientific, Rockford, IL), using bovine serum albumin (BSA) as a standard. An equal 
amount of protein $(30 \mu \mathrm{g})$ was loaded into SDS-polyacrylamide gel and separated by an electrophoresis unit (Cleaver Scientific Ltd, UK). After separation, the proteins were transferred onto polyvinylidene fluoride membranes (Bio-Rad) for 35 min, blocked in 5\% BSA in Tris-buffered saline containing $0.05 \%$ Tween, TBST. The membranes were then incubated with the primary antibody diluted in BSA $(1: 1000)$ at $4{ }^{\circ} \mathrm{C}$ overnight and washed 4 times with $1 \times$ TBST buffer. The secondary antibody (coupled to horseradish peroxidase) diluted in TBST buffer (1:2000) was added for $60 \mathrm{~min}$ at RT. The band signals were detected by Western Lightning enhanced chemiluminescence (ECL) reagents (Perkin Elmer, Waltham, MA), and captured by Chemi-Doc imager (Bio-Rad). The band intensities were calculated with normalization to the $\beta$-actin. ${ }^{63-65}$

\section{Molecular Docking}

Molecular operating environment (MOE) 2014 software was used to execute the molecular docking study. The crystal structure of VEGFR-2 (ID: 3VHE) was downloaded from PDB software. The downloaded protein is composed of one peptide chain, the co-crystallized ligand, and water molecules. The water molecules were eliminated, then protonation of 3D was done. The energy of the protein was minimized according to the default option (Forcefiled: MMFF94X, eps=r, cutoff] $8-10$ [). The pocket was obtained by isolating the receptor surface within $4.5 \AA$ around the ligand atoms. Validation of the docking protocol was detected by redocking the ligand (pyrrolopyrimidine inhibitor). It was found that the RMSD of the redocked ligand was of $0.42 \AA$ from the co-crystallized ligand. It was reported that RMSD of $1.5 \AA$ or less is an indicator for validation of the docking procedure. The new derivatives were constructed at MOE, 3D protonation was done, and the energy of the new derivative was minimized based on the default option. The prepared 3D structures were added to a created database. Docking of the prepared database into the pocket was done according to the default protocol. MOE produced database results containing the scores of the best conformers in $\mathrm{kcal} / \mathrm{mol}$. 2D and 3D interactions between the conformers and the binding site of the enzyme were obtained. ${ }^{66-68}$

\section{Statistical Analysis}

The biological parts were investigated in triplicates $(n=3)$ and all data were expressed as Mean \pm SEM. The significance of statistical analysis was assessed by the unpaired $t$-test to compare the mean of two independent groups using graph Pad Prism software 8 , and differences were considered statistically significant at $p$-values $<0.05$.

\section{Results and Discussion}

\section{Chemistry}

Preparation of the intermediates, $\mathbf{3}_{\mathbf{a}-\mathbf{g}}$ and $\mathbf{5}$, was achieved by treatment of an appropriate amine with chloroacetyl chloride as illustrated in Scheme 1.

Synthesis of 2-chloro-3-(piperazin-1-yl)quinoxaline (9) was carried out according to the procedure which involves reaction of oxalic acid with o-phenylenediamine in $4 \mathrm{~N} \mathrm{HCl}$ to afford quinoxaline-2,3-dione which was then treated with $\mathrm{POCl}_{3}$ in presence of DMF to give 2,3-dichloroquinoxaline (8). Treatment of compound $\mathbf{8}$ with piperazine in absolute ethanol and in the presence of triethylamine gave compound 9 (Scheme 2).

Stirring of 2-chloro-3-(piperazin-1-yl)quinoxaline (9) in aqueous $\mathrm{NaOH}$ solution for $24 \mathrm{~h}$ at $50{ }^{\circ} \mathrm{C}$ resulted in 3-(piperazin-1-yl)quinoxalin-2(1H)-one (12) as presented in Scheme 3.

Finally, compounds $\mathbf{1 0}_{\mathbf{a}-\mathrm{g}}$ and $\mathbf{1 1}$ were obtained by treatment of compound $\mathbf{9}$ with $\mathbf{3}_{\mathbf{a}-\mathrm{g}}$ and $\mathbf{5}$, as shown in Scheme 2. While treatment of compound 12 with $\mathbf{3}_{\mathrm{a}-\mathrm{g}}$ and $\mathbf{5}$ afforded the final compounds: $\mathbf{1 3}_{\mathrm{a}-\mathrm{g}}$ and $\mathbf{1 4}$, respectively (Scheme 3 ).

${ }^{1}$ H NMR charts of the new derivatives revealed that the 8 protons of the piperazine moiety appeared in two peaks; each was of 4 protons integration; the first peak was at $\delta$ value about $2.7 \mathrm{ppm}$, and the second one extended from 3.6 to $3.9 \mathrm{ppm}$. The peak of aromatic NH of acetanilide appeared at $\delta$ value ranging from 9.6 to $10.4 \mathrm{ppm}$. Its chemical shift was affected by the substituent at the benzene ring; it appeared shielded at $9.6 \mathrm{ppm}$ by the electron donating effect of the methoxy group, but it was deshielded to appear at $10.4 \mathrm{ppm}$ by the negative mesomeric effect of the nitro group. The aliphatic $\mathrm{NH}$ of compounds $\mathbf{1 1}$ and $\mathbf{1 4}$ were observed triplet at $8.4 \mathrm{ppm}$. Oxoquinoxaline derivatives showed a characteristic peak at about 12.12, ppm which is attributed to the NH of the quinoxalin-2-one nucleus. 
<smiles>[R]c1ccc(NC(=O)CCl)cc1</smiles>

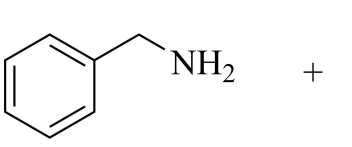

4<smiles>O=C(Cl)CCl</smiles>

2<smiles>O=C(CCl)NCc1ccccc1</smiles>

5

\begin{tabular}{|cc|}
\hline Comp no. & $\mathbf{R}$ \\
3a & $\mathbf{H}$ \\
3b & $\mathrm{OCH}_{3}$ \\
3c & $\mathbf{C l}$ \\
3d & $\mathbf{F}$ \\
$3 \mathbf{e}$ & $\mathrm{CH}_{3}$ \\
3f & $\mathrm{COCH}_{3}$ \\
3g & $\mathrm{NO}_{2}$ \\
\hline
\end{tabular}

Scheme I General procedures for preparation of intermediates 3a-g and 5; conditions: (i) DMF, NaHCO3, ice bath, stirring, Ih.

${ }^{13} \mathbf{C}$ NMR charts of the new derivatives showed peaks at about $169 \mathrm{ppm}$ due to quinoxaline carbon attached to the piperazine moiety. They also demonstrated peaks at about $152 \mathrm{ppm}$ due to $\mathrm{CO}$ of acetanilide. While the $\mathrm{CO}$ of quinoxalin2-one nucleus appeared at about $151 \mathrm{ppm}$. The ketone CO of compounds $\mathbf{1 0}_{\mathbf{f}}$ and $\mathbf{1 3}_{\mathbf{f}}$ showed a characteristic peak at 197 $\mathrm{ppm}$. The aromatic carbon attached to the methoxy group revealed a characteristic peak at about $155 \mathrm{ppm}$.

\section{Biological Testing} In vitro Antitumor Assay

All the new molecules have been evaluated against 4 cancer cell lines: A549 lung cancer cells, HepG-2 hepatoma cells, Caco-2 colon cancer cells, and MDA breast cancer cells, which were obtained from American Type Culture Collection (ATCC, USA). Sorafenib was used as a standard anticancer agent.

The data presented in Table 1 indicate that the most sensitive cell line to the new candidates was A549. We can notice that all the new derivatives, except compound 14, were more potent than sorafenib, which showed an $\mathrm{IC}_{50}$ of $14.10 \mu \mathrm{M}$. The most potent candidate was $\mathbf{1 0}_{\mathrm{b}}$, with an $\mathrm{IC}_{50}$ of $6.48 \mu \mathrm{M}$; it demonstrated about twice the potency of sorafenib. Additionally, compounds $\mathbf{1 0}_{\mathbf{g}}, \mathbf{1 0}_{\mathbf{a}}, \mathbf{1 0}_{\mathbf{c}}, \mathbf{1 0}_{\mathbf{f}}, \mathbf{1 1}, \mathbf{1 0}_{\mathbf{d}}$, and $\mathbf{1 3}_{\mathbf{b}}$ were far better than sorafenib, and they showed $\mathrm{IC}_{50}=8.36$, 9.03, 9.57, 10.31, 10.61, 10.90, and $10.97 \mu \mathrm{M}$, respectively. In general, 3-chloroquinoxaline derivatives displayed more potent results against A549 cells than 3-oxoquinoxaline compounds.

HepG-2 cell line came second in terms of sensitivity to the synthesized compounds. But in contrast to A549 cells, HepG-2 was more sensitive to 3-oxoquinoxaline derivatives than 3-chloroquinoxaline derivatives. Compounds $\mathbf{1 3}$ e $\mathbf{1 0}_{\mathbf{e}}$, $\mathbf{1 3}_{\mathbf{b}}, \mathbf{1 3}_{\mathbf{d}}$, and $\mathbf{1 3}_{\mathbf{f}}$ were found to be the most promising candidates with $\mathrm{IC}_{50}=7.82,8.08,8.35,8.40$, and $8.85 \mu \mathrm{M}$, respectively (Table 1). The results of these derivatives were weaker but close to sorafenib, which showed an $\mathrm{IC}_{50}$ of 7.31 $\mu \mathrm{M}$. With the exception of compound $\mathbf{1 0}_{\mathbf{b}}$, the results of new compounds were considerable; $\mathrm{IC}_{50}$ ranged from 9.52 to $14.62 \mu \mathrm{M}$.

Regarding Caco-2 cells, we can notice that compounds $\mathbf{1 3} \mathbf{f}$ and $\mathbf{1 3 _ { \mathbf { c } }}$ were more potent than sorafenib; they showed $\mathrm{IC}_{50}=9.01$ and $9.05 \mu \mathrm{M}$, respectively, compared to $9.25 \mu \mathrm{M}$ for sorafenib. Compound $\mathbf{1 0}_{\mathbf{c}}$ demonstrated an $\mathrm{IC}_{50}=9.42$ 
<smiles>Nc1ccccc1N</smiles>

6<smiles></smiles>

7<smiles>Clc1nc2ccccc2nc1Cl</smiles>

8<smiles>[R]c1ccc(NC(=O)CN2CCN(c3nc4ccccc4nc3Cl)CC2)cc1</smiles>

$10_{\mathrm{a}-\mathrm{g}}$

\begin{tabular}{|cc|}
\hline Comp no. & $\mathbf{R}$ \\
$10 \mathrm{a}$ & $\mathrm{H}$ \\
$10 \mathrm{~b}$ & $\mathrm{OCH}_{3}$ \\
$10 \mathrm{c}$ & $\mathrm{Cl}$ \\
$10 \mathrm{~d}$ & $\mathrm{~F}$ \\
$10 \mathrm{e}$ & $\mathrm{CH}_{3}$ \\
$10 \mathrm{f}$ & $\mathrm{COCH}_{3}$ \\
$10 \mathrm{~g}$ & $\mathrm{NO}_{2}$ \\
\hline
\end{tabular}<smiles>Clc1nc2ccccc2nc1N1CCNCC1</smiles>

9<smiles>[3H][Mg]</smiles><smiles>O=C(CN1CCN(c2nc3ccccc3nc2Cl)CC1)NCc1ccccc1</smiles>

11

Scheme 2 General procedures for preparation of final compounds IOa-g and II; Reagents and conditions: (i) oxalic acid, $\mathrm{HCl}, \mathrm{H} 2 \mathrm{O}$, reflux. (ii) POCl3, DMF, reflux, 3h. (iii) piperazine, Et $3 \mathrm{~N}$, absolute ethanol, ice bath. (iv) acetonitrile, $\mathrm{NaHCO}$, reflux, $2 \mathrm{~h}$.

$\mu \mathrm{M}$, which was comparable to that of sorafenib. Moreover, the data of compounds $\mathbf{1 3}_{\mathbf{b}}, \mathbf{1 1}, \mathbf{1 3}_{\mathbf{d}}$, and $\mathbf{1 3}_{\mathbf{a}}$ were significant, exhibiting $\mathrm{IC}_{50}=10.46,12.45,12.98$, and $13.17 \mu \mathrm{M}$, respectively. Caco-2 was similar to HepG-2 in that 3-oxoquinoxaline derivatives showed better results than those of 3-chloroquinoxaline derivatives.

Finally, MDA sensitivity was higher to the effect of 3-chloroquinoxaline derivatives than 3-oxoquinoxaline derivatives. Compound $\mathbf{1 0}_{\mathrm{g}}$ was found to be the most promising candidate, with an $\mathrm{IC}_{50}=10.52 \mu \mathrm{M}$. Compared to sorafenib, which revealed an $\mathrm{IC}_{50}=10.75 \mu \mathrm{M}, \mathbf{1 0}_{\mathbf{g}}$ was slightly better. Furthermore, compounds $\mathbf{1 0}_{\mathbf{c}}, \mathbf{1 1}, \mathbf{1 0}_{\mathbf{b}}$, and $\mathbf{1 3}_{\mathbf{c}}$ showed activities close to that of sorafenib; they demonstrated $\mathrm{IC}_{50}=11.27,11.52,11.60$, and $12.09 \mu \mathrm{M}$, respectively.

Initially, the cytotoxic effect of all the new derivatives was examined against the WISH normal cell line. The results given in Table 1 reveal good degrees of selectivity. It can be noticed that the results of compound $\mathbf{1 1}$ are of particular significance. It exhibited selectivity indices $=12.18,13.57,10.38$, and 11.22 to A549, HepG-2, Caco-2, and MDA cell lines, respectively. The second most selective compound was $\mathbf{1 3}_{\mathbf{b}}$; its selectivity indices were 9.94, 12.35, 10.42, and 7.40 to the four cell lines, respectively. Compound $\mathbf{1 0}_{\mathbf{e}}$ came in third place, with selectivity indices $=9.18,13.17,6.51$, and 7.43 to the four cell lines, respectively. Furthermore, compounds $\mathbf{1 3}_{\mathbf{a}}, \mathbf{1 0}_{\mathrm{g}}, \mathbf{1 3}_{\mathrm{f}}, \mathbf{1 3}_{\mathbf{d}}, \mathbf{1 0}_{\mathbf{f}}, \mathbf{1 0}_{\mathbf{c}}, \mathbf{1 0}_{\mathbf{d}}, \mathbf{1 3}_{\mathrm{e}}$, and $\mathbf{1 0}_{\mathrm{b}}$ showed good selectivity to one or more cancer cell lines.

Compounds $11,13_{b}, 10_{e}, 13_{\mathbf{a}}, \mathbf{1 0}_{\mathrm{g}}, \mathbf{1 3}_{\mathbf{f}}$, and $13_{\mathbf{d}}$, which showed the most valuable results in cytotoxicity testing, have been selected for further evaluation against VEGFR-2 kinase. 
<smiles>CC(C)C1CCCCC1</smiles>

9<smiles>[R]c1ccc(NC(=O)CN2CCN(c3nc4ccccc4[nH]c3=O)CC2)cc1</smiles>

\begin{tabular}{|cc|}
\hline Comp no. & R \\
$13 \mathrm{a}$ & $\mathrm{H}$ \\
$13 \mathrm{~b}$ & $\mathrm{OCH}_{3}$ \\
$13 \mathrm{c}$ & $\mathrm{Cl}$ \\
$13 \mathrm{~d}$ & $\mathrm{~F}$ \\
$13 \mathrm{e}$ & $\mathrm{CH}_{3}$ \\
$13 \mathrm{f}$ & $\mathrm{COCH}_{3}$ \\
$13 \mathrm{~g}$ & $\mathrm{NO}_{2}$ \\
\hline
\end{tabular}

Scheme 3 General procedures for synthesis of final compounds I3a-g and I4; Reagents and conditions: (i) $\mathrm{NaOH}, \mathrm{H} 2 \mathrm{O}$, stirring, $50^{\circ} \mathrm{C}$. (ii) acetonitrile, $\mathrm{NaHCO}$, reflux, $2 \mathrm{~h}$.

\section{VEGFR-2 (KDR) Kinase Assay}

The most prominent seven candidates $\left(\mathbf{1 1}, \mathbf{1 3}_{\mathbf{b}}, \mathbf{1 0}_{\mathbf{e}}, \mathbf{1 3}_{\mathbf{a}}, \mathbf{1 0}_{\mathbf{g}}, \mathbf{1 3}_{\mathbf{f}}\right.$, and $\left.\mathbf{1 3}_{\mathbf{d}}\right)$ were evaluated in vitro against VEGFR-2 kinase. The results presented in Table 2 show that the new derivatives managed to inhibit VEGFR-2 kinase at submicromolar concentrations. The $\mathrm{IC}_{50}$ values of the new derivatives ranged from 0.192 to $0.602 \mu \mathrm{M}$. It is apparent from the data supplied that the most significant derivative was compound 11; it exhibited an $\mathrm{IC}_{50}$ of $0.192 \mu \mathrm{M}$ compared to $0.082 \mu \mathrm{M}$ for sorafenib (the positive control). Concentration-dependent kinase inhibition plots of compound 11 and sorafenib are presented in Figure 2 and Figure 3, respectively. The second most potent derivative was compound $\mathbf{1 0}_{\mathbf{e}}$, with an $\mathrm{IC}_{50}=0.241 \mu \mathrm{M}$. Activity of the other candidates can be arranged in a descending order as follows: $\mathbf{1 3} \mathbf{a}_{\mathbf{a}}\left(\mathrm{IC}_{50}=0.258 \mu \mathrm{M}\right), \mathbf{1 0}_{\mathbf{g}}\left(\mathrm{IC}_{50}=0.332 \mu \mathrm{M}\right), \mathbf{1 3}_{\mathbf{f}}\left(\mathrm{IC}_{50}=0.465 \mu \mathrm{M}\right), \mathbf{1 3}_{\mathbf{b}}\left(\mathrm{IC}_{50}=0.471 \mu \mathrm{M}\right)$, and $\mathbf{1 3}_{\mathbf{d}}$ $\left(\mathrm{IC}_{50}=0.602 \mu \mathrm{M}\right)$.

VEGFR-2 inhibitors have been shown to induce apoptosis. ${ }^{51}$ So, we evaluated cell cycle kinetics and apoptosis rates in HepG-2 treated with compound 11, which was the most potent VEGFR-2 inhibitor candidate. We aimed to examine reasons other than VEGFR-2 inhibition behind the significant antitumor results of the new derivatives. 
Table I IC 50 Values of the New Derivatives and the Reference Sorafenib Against Four Cancer Cell Lines, A549, HepG-2, Caco-2 and MDA as Well as One Normal Cell Line (WISH)

\begin{tabular}{|c|c|c|c|c|c|c|}
\hline \multirow[t]{2}{*}{ Serial } & \multirow[t]{2}{*}{ Comp. ID } & \multicolumn{5}{|c|}{$I C_{50}(\mu M)^{a}$} \\
\hline & & A549 & HepG-2 & Caco-2 & MDA & WISH \\
\hline I & $10_{a}$ & 9.03 & 14.62 & 14.17 & 14.38 & 30.50 \\
\hline 2 & $10_{b}$ & 6.48 & 469.00 & 14.64 & 11.60 & 45.66 \\
\hline 3 & $10_{c}$ & 9.57 & 22.64 & 9.42 & 11.27 & 47.96 \\
\hline 4 & $10_{d}$ & 10.90 & 38.58 & 32.83 & 16.60 & 82.18 \\
\hline 5 & $10_{e}$ & 11.59 & 8.08 & 16.34 & 14.32 & 106.44 \\
\hline 6 & $10_{f}$ & 10.31 & 12.45 & 28.44 & 16.08 & 65.52 \\
\hline 7 & $10 \mathrm{~g}$ & 8.36 & 11.38 & 15.92 & 10.52 & 85.05 \\
\hline 8 & II & 10.61 & 9.52 & 12.45 & 11.52 & 129.27 \\
\hline 9 & $13 a$ & 11.24 & 11.54 & 13.17 & 17.91 & 105.56 \\
\hline 10 & $13 \mathrm{~b}$ & 10.97 & 8.83 & 10.46 & $|4.7|$ & 109.06 \\
\hline II & $13 c$ & 12.79 & 10.43 & 9.05 & 12.09 & 42.09 \\
\hline 12 & $13 \mathrm{~d}$ & 13.43 & 8.35 & 12.98 & 14.37 & 60.45 \\
\hline 13 & $13 \mathrm{e}$ & 12.60 & 7.82 & 14.35 & 18.47 & 39.65 \\
\hline 14 & $13_{f}$ & 11.33 & 8.40 & 9.01 & 16.45 & 54.83 \\
\hline 15 & $13 \mathrm{~g}$ & 10.49 & 12.60 & 19.41 & 24.63 & 38.60 \\
\hline 16 & 14 & 14.66 & 12.72 & 16.64 & 20.03 & 35.69 \\
\hline 17 & Sorafenib & 14.10 & 7.31 & 9.25 & 10.75 & $N T^{b}$ \\
\hline
\end{tabular}

Notes: ${ }^{a} \mid C_{50}$ values are the mean \pm S.D. of three separate experiments. ${ }^{b}$ Not tested.

Table 2 VEGFR-2 IC 50 of the Tested Derivatives Compared to Sorafenib

\begin{tabular}{|c|c|}
\hline Comp. ID & VEGFR-2, IC $50(\mu \mathrm{M})$ \\
\hline $10_{e}$ & $0.241 \pm 0.021$ \\
\hline $10_{g}$ & $0.332 \pm 0.028$ \\
\hline II & $0.192 \pm 0.016$ \\
\hline $13 a$ & $0.258 \pm 0.023$ \\
\hline $13 \mathrm{~b}$ & $0.471 \pm 0.034$ \\
\hline $13_{d}$ & $0.602 \pm 0.048$ \\
\hline $13_{f}$ & $0.465 \pm 0.046$ \\
\hline Sorafenib & $0.082 \pm 0.023$ \\
\hline
\end{tabular}




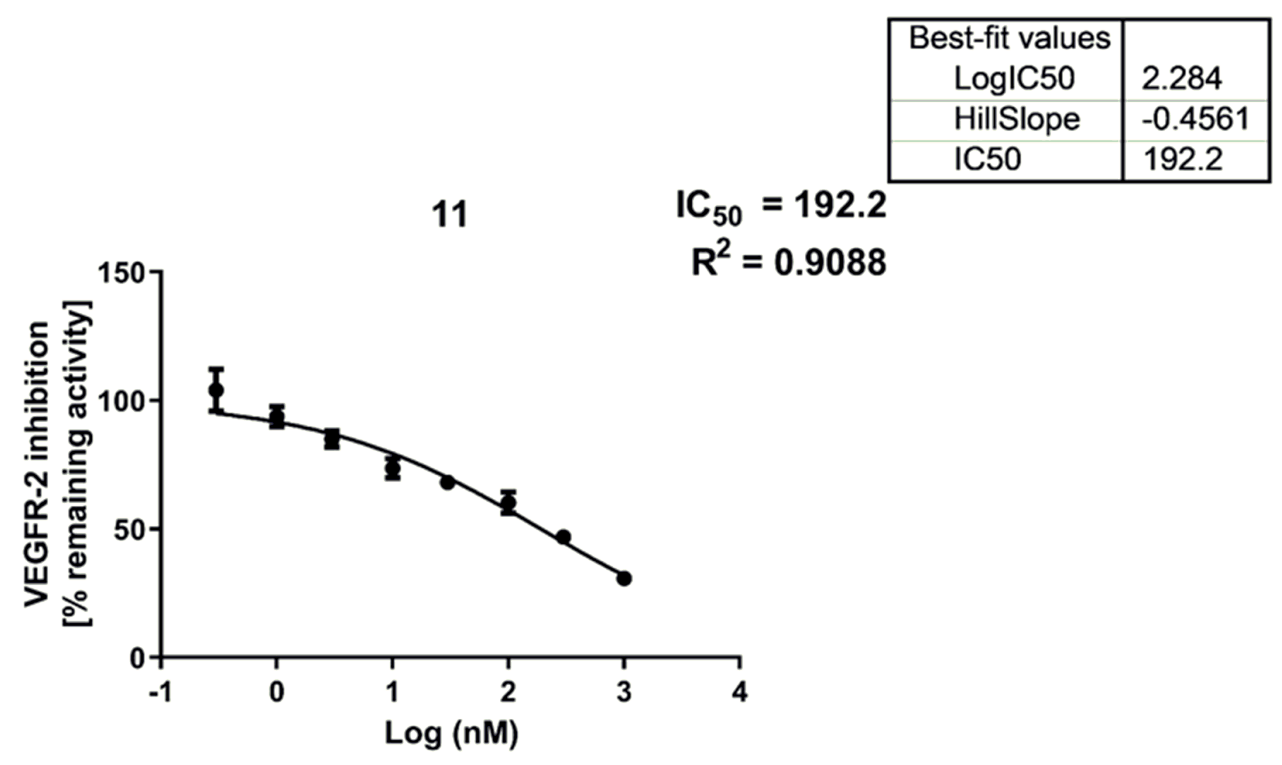

Figure 2 Concentration dependent kinase inhibition plot of compound II. The percent VEGFR-2 inhibition was determined for compound II relative to control, and the data were fitted to the dose-response curve to obtain IC50 values. Error bars represent SEM of three replicates.

\section{Effect on Cell Cycle Kinetic}

It is clear from Figure 4 that $9.52 \mu \mathrm{M}$ of compound 11 displayed a strong impact on the different cell cycle phases of HepG-2 cells compared to control cells. We can notice that the most significant increase in cell accumulation rate was at S phase, from $20.14 \%$ to $46.10 \%$. Also, cell accumulation in the G2/M phase was increased from $15.16 \%$ to $25.22 \%$. On the other hand, there was a sharp decrease in cell accumulation percentage in phase G1 from $63.18 \%$ to $27.37 \%$.

\section{Annexin V-FITC Apoptosis Assay}

It is apparent from the results illustrated in Table 3 and Figure 5 that there was a sharp increase in HepG-2 cells apoptosis due to the effect of $9.52 \mu \mathrm{M}$ ( $\mathrm{IC}_{50}$ value) of compound 11. As can be seen, the early apoptosis rate was increased exponentially by about 9 -fold, from $4.75 \%$ to $43.60 \%$. At the same time, late apoptosis was increased by

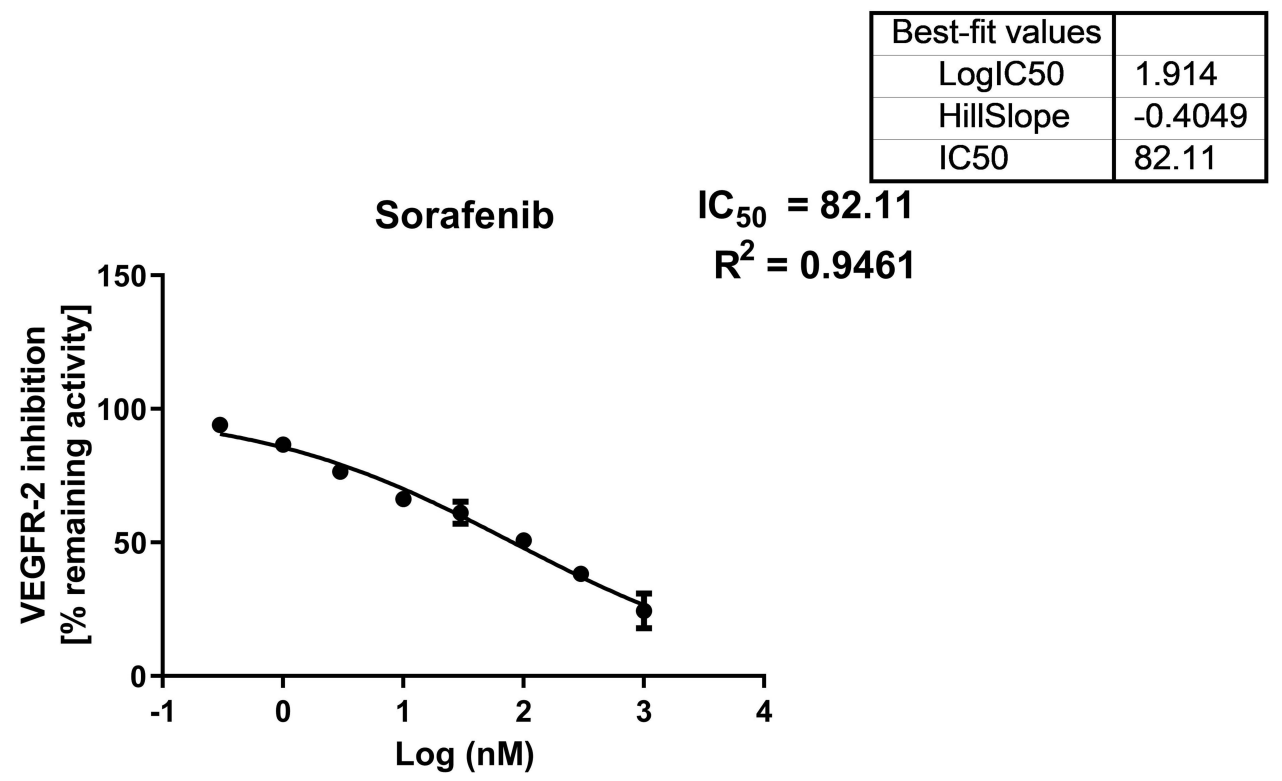

Figure 3 Concentration dependent kinase inhibition plot of sorafenib. The percent VEGFR-2 inhibition was determined for sorafenib relative to control, and the data were fitted to the dose-response curve to obtain IC50 values. Error bars represent SEM of three replicates. 


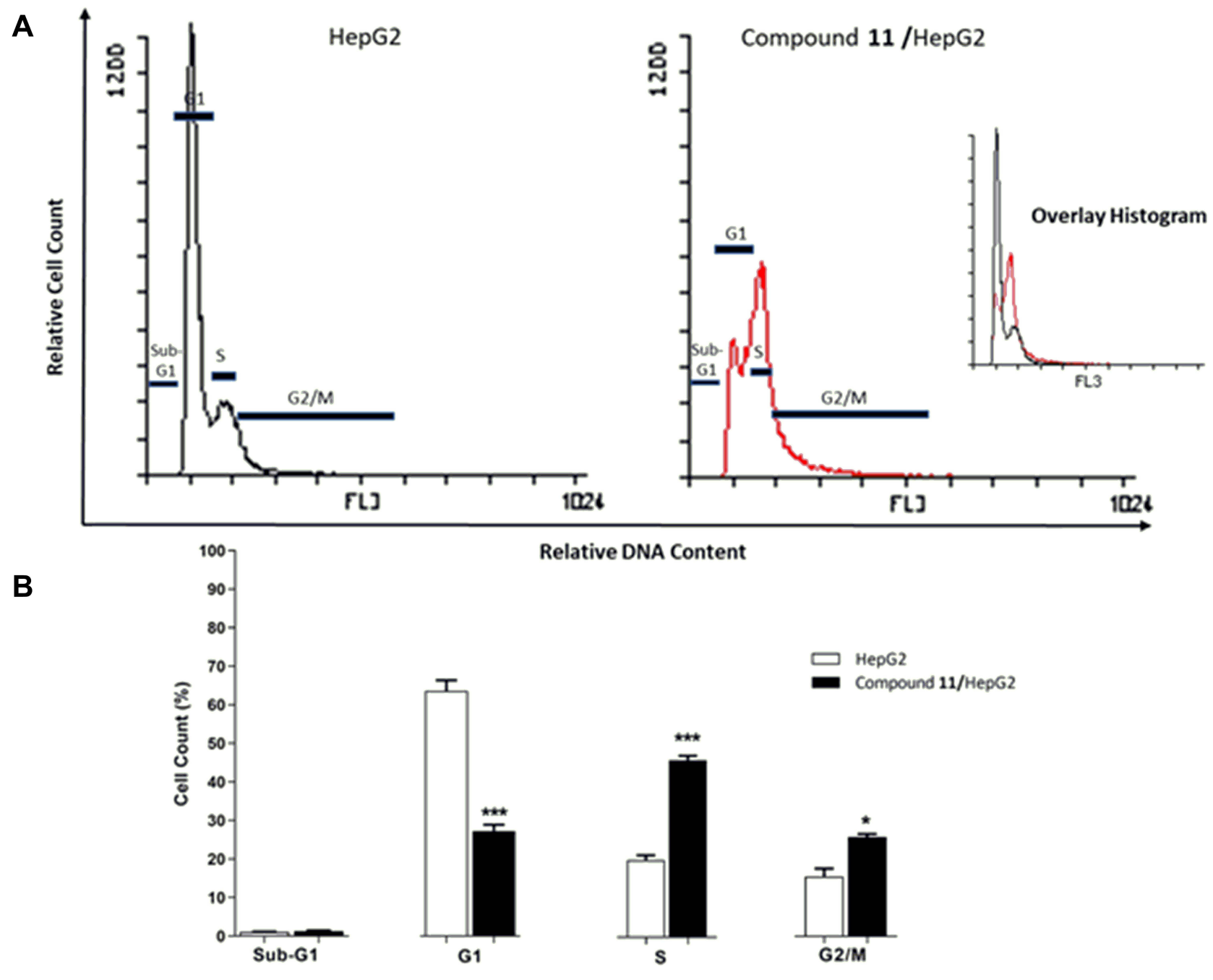

Figure 4 Flow cytometric analysis of HepG-2 cell cycle phases after $48 \mathrm{~h}$ treatment with $9.52 \mu \mathrm{M}$ (IC 50 value) of compound I I. After treatment with I I, HepG-2 cells were harvested, stained and then cell cycle phases were analyzed using Flowing software. (A) Illustrating histograms show the cell cycle distribution of both HepG-2 test cells and control. (B) Column diagram represents percentage of cells accumulation in the different phases of cell cycle. Results have been calculated as mean \pm SEM of 3 experiments. ${ }^{*} p<0.05, *^{* *} p<0.001$ statistically indicate the significance of the obtained results compared to control $(\mathrm{HepG}-2)$.

3-fold compared to control. On the other hand, the given information revealed a weak effect of compound $\mathbf{1 1}$ on HepG-2 necrosis. Additionally, there was a dramatic decrease in HepG-2 viable cells from $95.54 \%$ to $55.95 \%$ due to the effect of compound 11. Further evaluation was carried out to explore the mechanism of apoptosis induced by compound 11.

Table 3 Apoptosis and Necrosis Rates of HepG-2 Cells Treated with Compound II Compared to Control HepG-2 Cells

\begin{tabular}{|l|c|c|c|c|}
\hline \multirow{2}{*}{ Cell Type } & \multirow{2}{*}{ Viable $^{\mathrm{a}}$} & \multicolumn{2}{|c|}{ Apoptosis $^{\mathrm{a}}$} & \multirow{2}{*}{ Necrosis $^{\text {a }}$} \\
\cline { 3 - 4 } & & Early & Late & \\
\hline HepG-2 & $95.54 \pm 1.94$ & $4.75 \pm 0.48$ & $0.13 \pm 0.01$ & $0.11 \pm 0.01$ \\
\hline $\mathrm{II} / \mathrm{HepG}-2$ & $55.95 \pm 4.19$ & $43.60 \pm 4.16 * * *$ & $0.38 \pm 0.09$ & $0.17 \pm 0.01$ \\
\hline
\end{tabular}

Notes: ${ }^{a}$ Values have been supplied as mean \pm SEM of 3 experiments. $* * * p<0.00$ I statistically indicate the significance of the obtained values compared to control (HepG-2). 

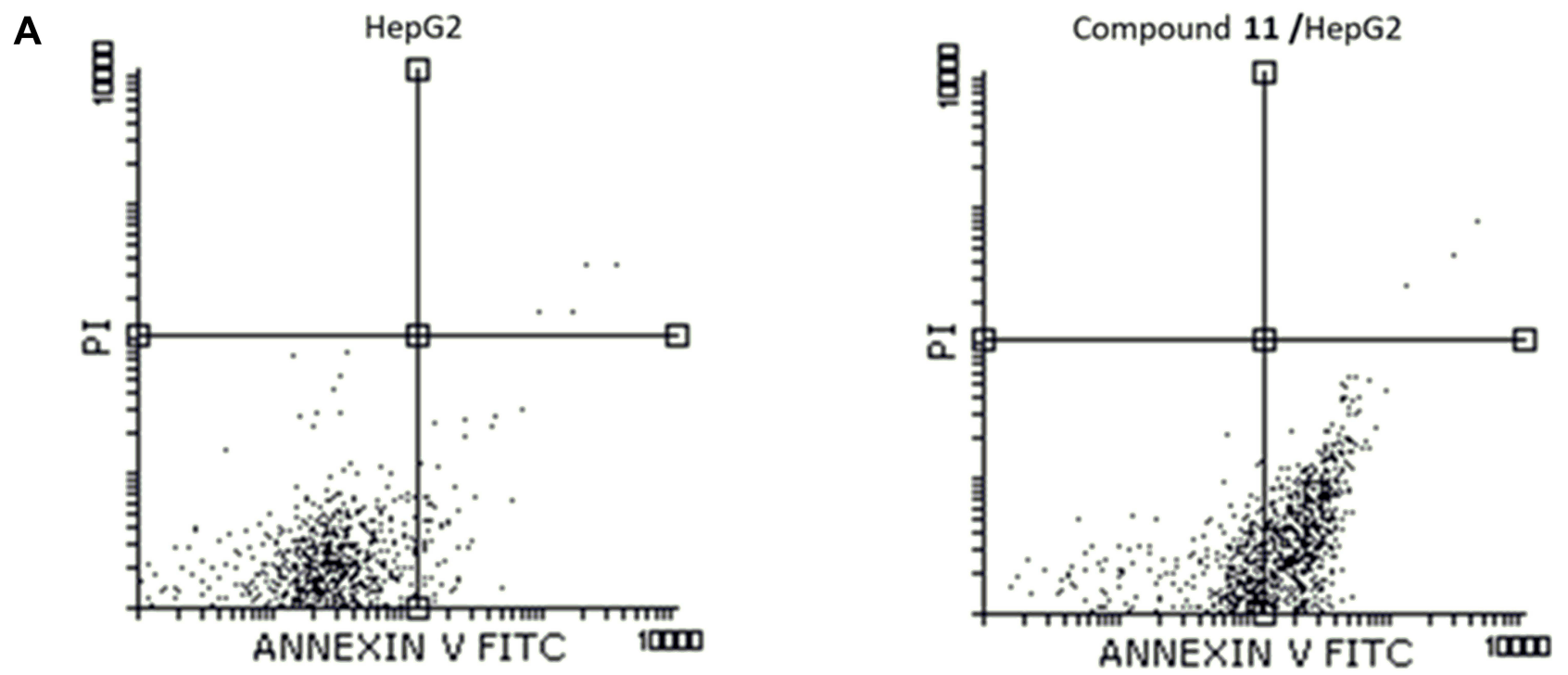

\section{B}

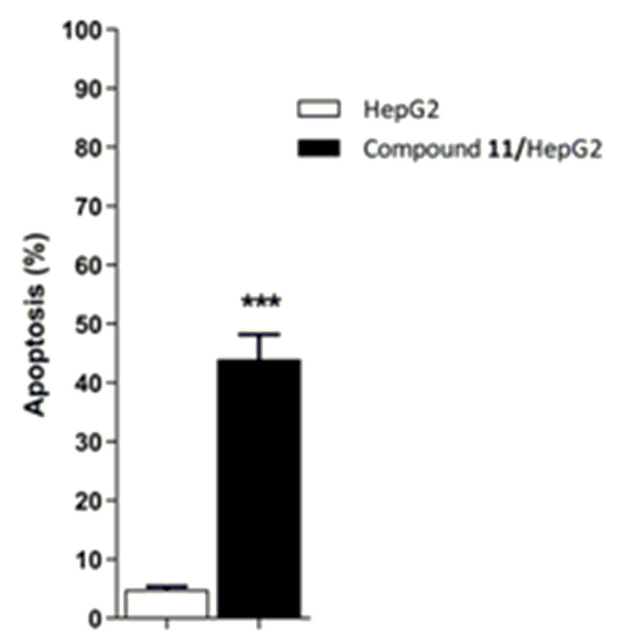

Figure 5 Apoptosis rate in HepG-2 cells treated with $(9.52 \mu \mathrm{M})$ of compound II for $48 \mathrm{~h}$ in comparison to control HepG-2 cells. (A) The obtained flow cytometric figures for both test and control HepG-2 cells. (B) Data from quantification of apoptosis are presented as mean \pm SEM of 3 experiments. ****p $<0.00$ l statistically indicate the significance of the obtained results in comparison to control (HepG-2).

\section{Effect on Levels of BAX and Bcl-2 Protein Expression}

Western blot analysis provided data concerning the effect of $9.52 \mu \mathrm{M}\left(\mathrm{IC}_{50}\right.$ value) of compound 11 on the expression of certain proteins in HepG-2 cells treated for 48h, as shown in Table 4 and Figure 6. It is clear from the results given that there was a double increase in BAX protein expression level compared to control HepG-2 cells. Meanwhile, Bcl-2 expression level decreased to half compared to control cells. Accordingly, a 4-fold rise in the BAX/Bcl-2 ratio was obtained. BAX was reported as a proapoptotic member of the Bcl-2 family. On the other hand, Bcl-2 is an antiapoptotic protein. $^{52,53}$

\section{Effect on Caspase-3 Level}

Caspase-3 is known as the primary executioner caspase in apoptosis. ${ }^{54,55}$ Caspase-3 level was increased by 2.3 -fold in HepG-2 cells treated with compound $\mathbf{1 1}(9.52 \mu \mathrm{M})$ compared to untreated cells, as presented in Figure 6 and Table 4.

\section{Effect on P53 Level}

Further evaluation of compound $\mathbf{1 1}\left(\mathrm{IC}_{50}\right.$ value) at HepG-2 showed an effective rise in the expression level of the tumor suppressor protein p53. A 3-fold increase in the expression level of p53 can be seen in Figure 6 and Table 4. P53 protein 
Table 4 The Impact of Compound I I on Expression of the Tested Proteins in HepG-2 Cells Treated For 48 h

\begin{tabular}{|l|c|c|c|c|c|}
\hline \multirow{2}{*}{ Cell type } & \multicolumn{5}{|c|}{ Protein Level (Normalized to $\beta$-Actin) ${ }^{\text {a }}$} \\
\cline { 2 - 7 } & BAX & Bcl-2 & BAX/Bcl-2 Ratio & Caspases-3 & P53 \\
\hline HepG-2 & $1.00 \pm 0.03$ & $1.00 \pm 0.09$ & $1.00 \pm 0.11$ & $1.00 \pm 0.10$ & $1.00 \pm 0.03$ \\
I I/HepG-2 & $2.16 \pm 0.22 * *$ & $0.50 \pm 0.03 *$ & $4.25 \pm 0.47 * *$ & $2.32 \pm 0.1 I_{* * *}$ & $3.07 \pm 0.24 * *$ \\
\hline
\end{tabular}

Notes: ${ }^{a}$ Results are supplied as mean \pm SEM of 3 experiments. ${ }^{*} \mathrm{p}<0.05,{ }^{*} \mathrm{p}<0.0$ I, ${ }^{* * *} \mathrm{p}<0.00 \mathrm{I}$ indicate the significance of the obtained values statistically.

was reported to have many biological activities, such as apoptosis, DNA repair, and cell cycle arrest. ${ }^{56-59}$ It was also proven to inhibit tumor angiogenesis. ${ }^{59}$

The data obtained from Western blot analysis reveals that the apoptosis inducing effect of compound $\mathbf{1 1}$ is more likely to be attributed to its ability to increase the $\mathrm{BAX} / \mathrm{Bcl}-2$ ratio and levels of caspase- 3 and p53 proteins.

\section{Molecular Docking}

We carried out docking studies for the new derivatives and sorafenib (reference of biology) in order to get insights into their binding and affinity to VEGFR-2. The protein (ID: 3VHE) was downloaded with its co-crystallized ligand (pyrrolopyrimidine inhibitor) from protein data bank (PDB) web site. The redocked ligand showed a root mean square deviation (RMSD) of $0.42 \AA$ which means that the executed docking protocol was valid. Figure S1 in The supplementary data.pdf shows the overlay of the redocked and the co crystallized ligand. The supplied figure shows that the ligand displayed two hydrogen bonds with Glu885 and another one with Asp1046 via its urea moiety. One more hydrogen bond was formed between $\mathrm{NH}$ of the pyrrolopyrimidine nucleus and Cys919. Additionally, the planar aromatic moiety demonstrated a $\pi$ cation interaction with Leu1035.

Sorafenib binding mode was found to be similar to that of the ligand as shown Figure S2 in The supplementary data.pdf; the urea moiety showed two hydrogen bonds (length: $1.87 \AA$ and $1.97 \AA$ ) with Glu885 and another one

A

B

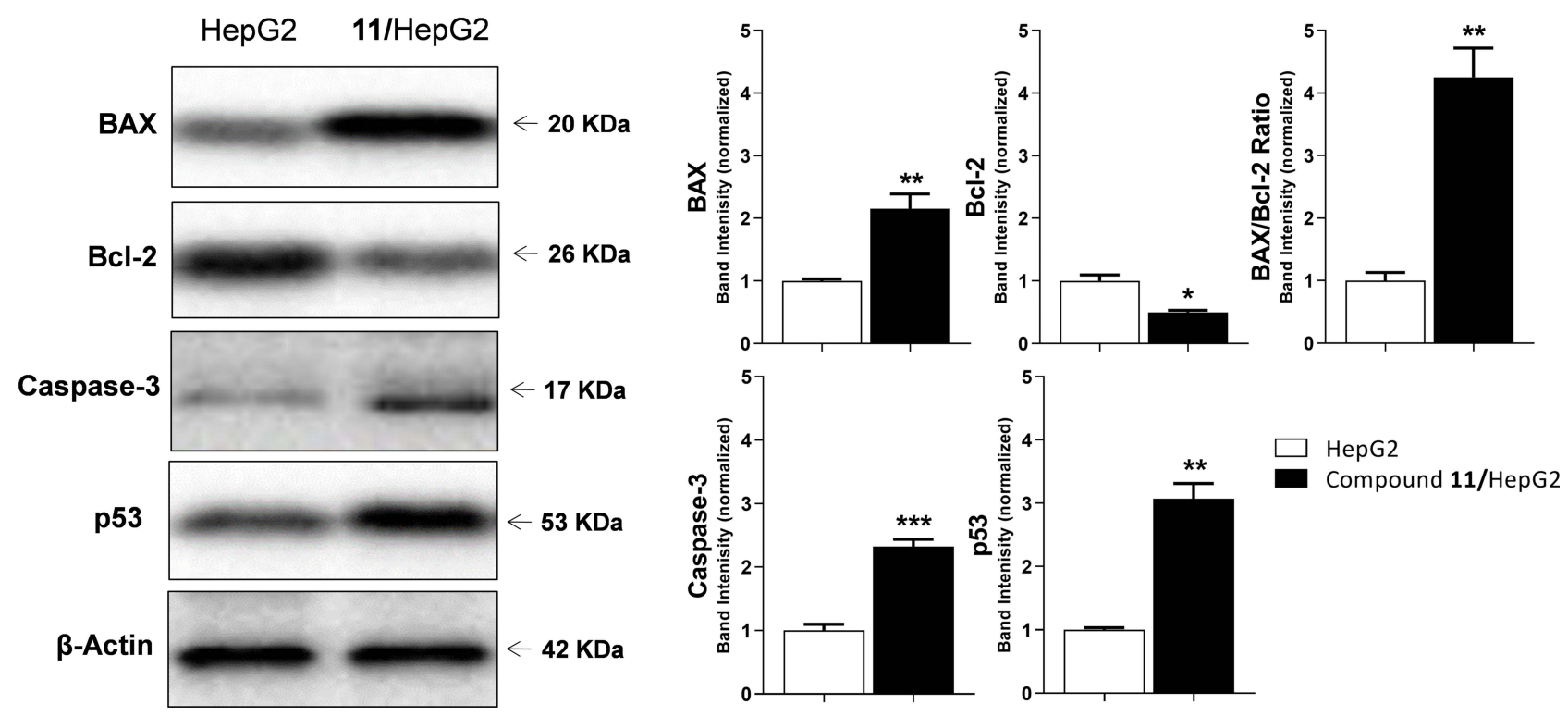

Figure 6 The immunoblotting of the expression of BAX, Bcl-2, Caspase-3, and p53 (Normalized to $\beta$-actin). (A) A given Western blot illustrations display the impact of 9.52 $\mu M\left(I_{50}\right.$ value) of compound II on the tested proteins expression in HepG-2 cells treated for $48 \mathrm{~h}$. (B) The evaluated proteins quantity in the cell lysates. The reference HepG-2 cells were set to "I", and all results from 3 experiments are presented as mean \pm SEM. $*_{p}<0.05, * * p<0.01$, ***p $<0.001$ indicate the importance of the obtained results statistically. 
(length: $1.77 \AA$ ) with Asp1046. Moreover, the phenoxy group showed a $\pi$ cation interaction with the alkyl side chain of Val899.

With respect to the new derivatives, it was found that all compounds showed a good fit to the pocket with binding modes similar to that of the ligand. Figure 7 represents the binding mode of compound 11; as can be seen the amide group demonstrated two hydrogen bonds (length: $1.75 \AA$ and $1.85 \AA$ ) with the essential amino acids Glu885 and Asp1046. Meanwhile, the quinoxaline moiety was oriented to occupy the ATP binding domain, showing a $\pi$ cation interaction with the alkyl side chain of Val848. It was also found that the terminal benzylic group was directed to form hydrophobic interactions with the alkyl side chains of Ile888, Leu889, and Ile892 in the allosteric pocket. Figure 8 reveals that the binding patterns of compound $\mathbf{1 1}$ and the co-crystallized ligand are almost the same. These data clearly suggest that compound $\mathbf{1 1}$ is proposed to bind correctly and efficiently with VEGFR-2 kinase.

The binding pattern of compound $\mathbf{1 0} \mathbf{e}$ was also found to be similar to the ligand (Figure S3 in supplementary materials); we can see in the figure that the amide group showed a hydrogen bond with Glu885 and Asp1046. The methylene group of acetanilide demonstrated a $\pi$ cation interaction with Glu885. The quinoxaline moiety revealed a $\pi$ cation interaction with Val848. The terminal aromatic moiety demonstrated a $\pi$ cation interaction with the alkyl side chain of Asp1046.

The binding mode of compound $\mathbf{1 3}_{\mathbf{a}}$ is presented in Figure S4 in the supplementary materials. The amide group showed a hydrogen bond with Glu885 and another one with Asp1046. Moreover, the quinoxaline moiety displayed an essential hydrogen bond with Glu917 and a $\pi$ cation interaction with Cys919. This $\pi$ cation interaction improved the binding affinity of compound $\mathbf{1 3}$ a.

\section{Structure Activity Relationship}

According to biological results obtained, relationships can be established between the structures and activities of the new derivatives as follows:

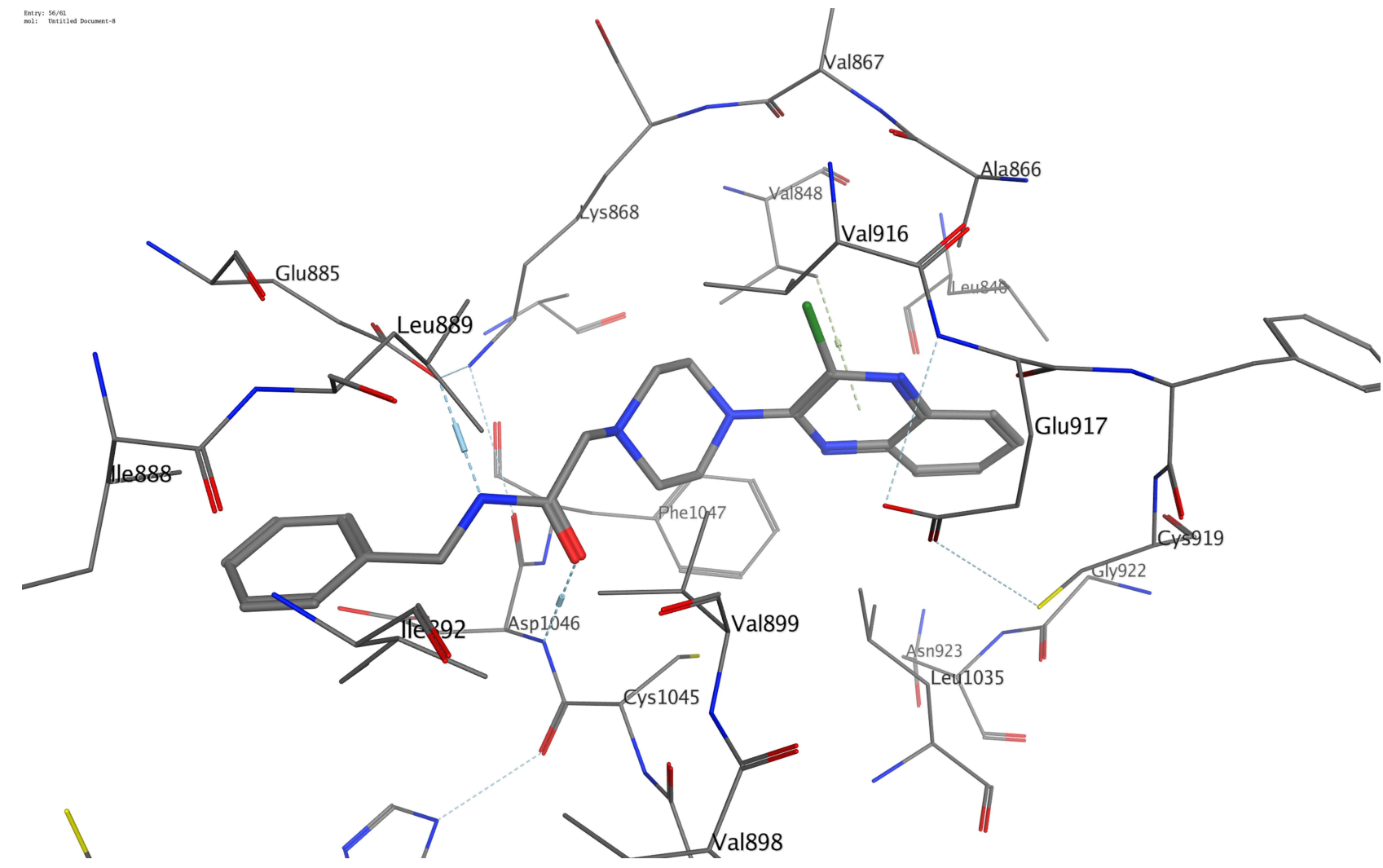

Figure 7 Binding mode of compound II. 


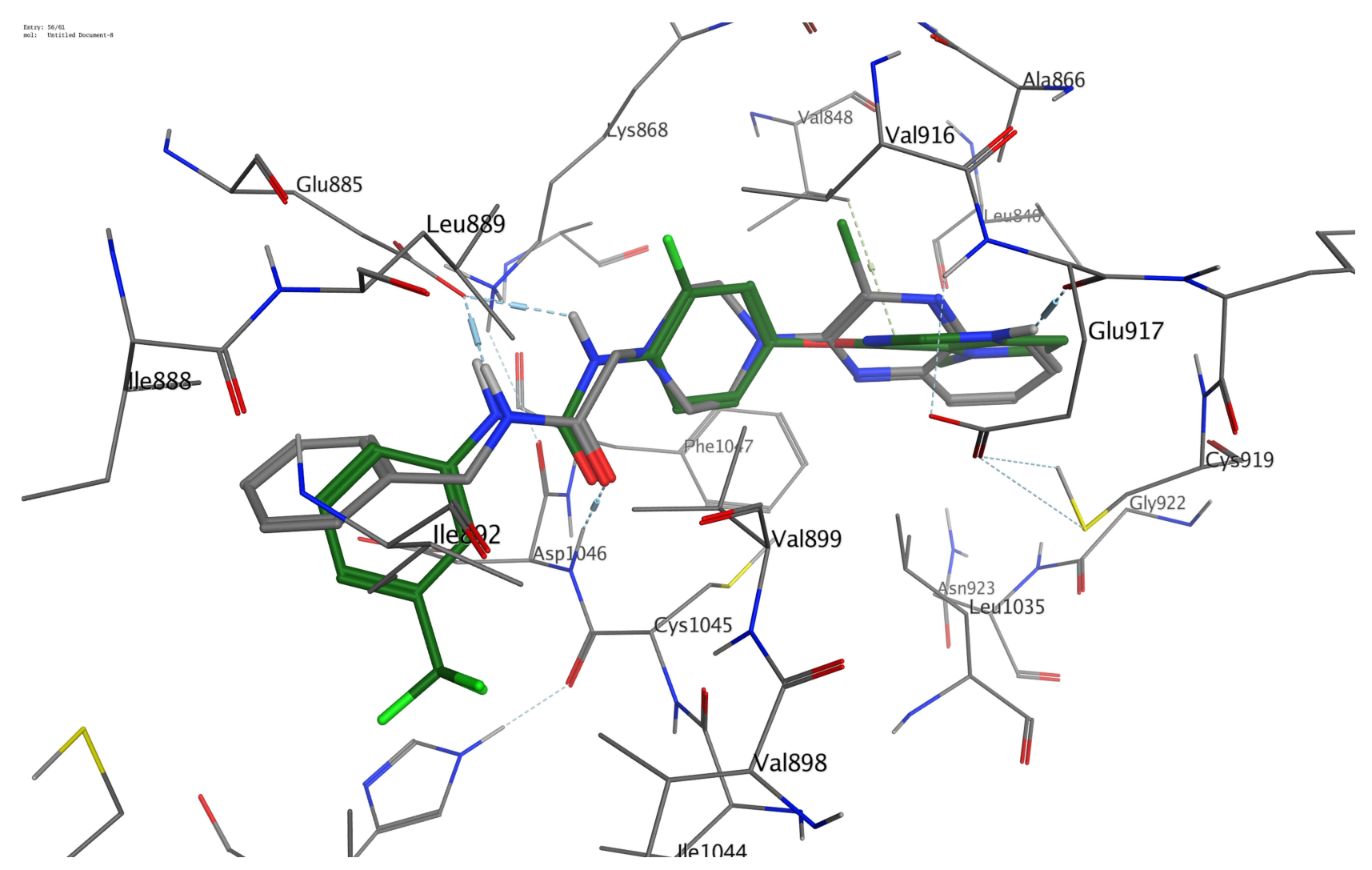

Figure 8 Overlay of compound II (gray colored) and the ligand (green colored).

1. Chloroquinoxaline derivatives are more potent antiproliferative agents against A549 and MDA than their corresponding oxoquinoxaline derivatives.

2. Regarding HepG-2 and Caco-2, oxoquinoxaline derivatives showed better activity than chloroquinoxaline derivatives.

3. The methoxy group at position 4 of the terminal phenyl ring revealed higher activity against A549 than other substituents at the same position.

4. 4-methylphenyl as a terminal hydrophobic moiety was the most potent against HepG-2.

5. 4-chlorophenyl as a terminal hydrophobic moiety was found to be the best against both Caco-2 and MDA.

6. With regard to VEGFR-2 inhibition, the chlorine atom at position 2 of quinoxaline was superior to the oxygen at the same position.

7. Non polar substituents at position- 4 of the terminal phenyl showed better activity than polar substituents in terms of VEGFR-2 inhibition.

\section{Conclusion}

In accordance with the reported pharmacophoric features of VEGFR-2 inhibitor agents and on the basis of the antihypertensive property of the piperazinylquinoxaline moiety, we designed and synthesized new sixteen piperazinylquinoxaline derivatives as potential safer antitumor candidates. The obtained data showed that the new derivatives revealed considerable antitumor activities against four cancer cell lines: A549, HepG-2, Caco-2, and MDA, with considerable degrees of selectivity to cancer cells. Meanwhile, the studied candidates managed to inhibit VEGFR-2 kinase at sub-micromolar concentrations. Accordingly, we suggest that future work on the new derivatives by modification and further evaluation would be more likely to develop potent anticancer agents targeting VEGFR-2 kinase.

The most significant candidate to be considered for further work was compound 11, which displayed an encouraging profile of biological results and in silico data. It showed $\mathrm{IC}_{50}=10.61,9.52,12.45$, and $11.52 \mu \mathrm{M}$ against A549, HepG-2, 
Caco-2, and MDA cell lines, respectively. While it showed $\mathrm{IC}_{50}$ of $129.27 \mu \mathrm{M}$ against the WISH normal cell. Additionally, it demonstrated an $\mathrm{IC}_{50}=0.192 \mu \mathrm{M}$ against VEGFR-2 kinase. Moreover, HepG-2 treated with $9.52 \mu \mathrm{M}$ of 11 revealed noticeable increases in BAX/Bcl-2 ratio, caspase-3 level, and P53 expression; these factors collectively account for the dramatic increase in apoptosis rate from $5 \%$ to about $44 \%$.

\section{Acknowledgment}

The authors extend their appreciation to the Research Center at AlMaarefa University for funding this work under TUMA project agreement number (TUMA-2021-4).

\section{Disclosure}

The authors report no conflicts of interest for this work.

\section{References}

1. Ma X, Yu H. Cancer issue: global burden of cancer. Yale J Biol Med. 2006;79(3-4):85.

2. Bray F, Ferlay J, Soerjomataram I, et al. Global cancer statistics 2018: GLOBOCAN estimates of incidence and mortality worldwide for 36 cancers in 185 countries. CA Cancer J Clin. 2018;68(6):394-424. doi:10.3322/caac.21492

3. El-Zahabi M. Design, molecular modeling and synthesis of new immunomodulatory agents for biological studies. Al-Azhar J Pharm Sci. 2021;64 (2):1-20. doi:10.21608/ajps.2021.187700

4. Sung H, Ferlay J, Siegel RL, et al. Global cancer statistics 2020: GLOBOCAN estimates of incidence and mortality worldwide for 36 cancers in 185 countries. CA Cancer J Clin. 2021;71(3):209-249. doi:10.3322/caac.21660

5. Ghosh S, Sullivan CAW, Zerkowski MP, et al. High levels of vascular endothelial growth factor and its receptors (VEGFR-1, VEGFR-2, neuropilin-1) are associated with worse outcome in breast cancer. Hum Pathol. 2008;39(12):1835-1843. doi:10.1016/j.humpath.2008.06.004

6. Seto T, Higashiyama M, Funai H, et al. Prognostic value of expression of vascular endothelial growth factor and its flt-1 and KDR receptors in stage I non-small-cell lung cancer. Lung Cancer. 2006;53(1):91-96. doi:10.1016/j.lungcan.2006.02.009

7. Duff SE, Jeziorska M, Rosa DD, et al. Vascular endothelial growth factors and receptors in colorectal cancer: implications for anti-angiogenic therapy. Eur J Cancer. 2006;42(1):112-117. doi:10.1016/j.ejca.2005.09.018

8. Chu JS, Ge FJ, Zhang B, et al. Expression and prognostic value of VEGFR-2, PDGFR- $\beta$, and c-Met in advanced hepatocellular carcinoma. $J$ Exp Clin Cancer Res. 2013;32(1):1-8. doi:10.1186/1756-9966-32-16

9. Xia G, Kumar SR, Hawes D, et al. Expression and significance of vascular endothelial growth factor receptor 2 in bladder cancer. $J$ Urol. $2006 ; 175$ (4):1245-1252. doi:10.1016/S0022-5347(05)00736-6

10. Basagiannis D, Zografou S, Murphy C, et al. VEGF induces signalling and angiogenesis by directing VEGFR2 internalisation through macropinocytosis. J Cell Sci. 2016;129(21):4091-4104. doi:10.1242/jcs.188219

11. Herkenne S, Paques C, Nivelles O, et al. The interaction of uPAR with VEGFR2 promotes VEGF-induced angiogenesis. Sci Signal. 2015;8(403): ra117-ra117. doi:10.1126/scisignal.aaa2403

12. Zhong M, Li N, Qiu X, et al. TIPE regulates VEGFR2 expression and promotes angiogenesis in colorectal cancer. Int J Biol Sci. $2020 ; 16(2): 272$. doi:10.7150/ijbs.37906

13. Nishida N, Yano H, Nishida T, et al. Angiogenesis in cancer. Vasc Health Risk Manag. 2006;2(3):213. doi:10.2147/vhrm.2006.2.3.213

14. Yang Y, Sun M, Wang L, et al. HIFs, angiogenesis, and cancer. J Cell Biochem. 2013;114(5):967-974. doi:10.1002/jcb.24438

15. Xu WW, Li B, Lam AK, et al. Targeting VEGFR1-and VEGFR2-expressing non-tumor cells is essential for esophageal cancer therapy. Oncotarget. 2015;6(3):1790. doi:10.18632/oncotarget.2781

16. Jung K, Heishi T, Khan OF, et al. Ly6C lo monocytes drive immunosuppression and confer resistance to anti-VEGFR2 cancer therapy. $J$ Clin Invest. 2017;127(8):3039-3051. doi:10.1172/JCI93182

17. Pysz MA, Foygel K, Rosenberg J, et al. Antiangiogenic cancer therapy: monitoring with molecular US and a clinically translatable contrast agent (BR55). Radiology. 2010;256(2):519-527. doi:10.1148/radiol.10091858

18. Fontanella C, Ongaro E, Bolzonello S, et al. Clinical advances in the development of novel VEGFR2 inhibitors. Ann Trans Med. 2014;2(12):123.

19. Abdallah AE, Eissa SI, Al Ward MMS, et al. Design, synthesis and molecular modeling of new quinazolin-4 (3H)-one based VEGFR-2 kinase inhibitors for potential anticancer evaluation. Bioorg Chem. 2021;109:104695. doi:10.1016/j.bioorg.2021.104695

20. Wilhelm S, Carter C, Lynch M, et al. Discovery and development of sorafenib: a multikinase inhibitor for treating cancer. Nat Rev Drug Discov. 2006;5(10):835-844. doi:10.1038/nrd2130

21. Strumberg D, Scheulen ME, Schultheis B, et al. Regorafenib (BAY 73-4506) in advanced colorectal cancer: a Phase I study. Br J Cancer. 2012;106 (11):1722-1727. doi:10.1038/bjc.2012.153

22. Subbiah V, Meric-Bernstam F, Mills GB, et al. Next generation sequencing analysis of platinum refractory advanced germ cell tumor sensitive to Sunitinib $\left(\right.$ Sutent $^{\mathbb{B}}$ ) a VEGFR2/PDGFRß/c-kit/FLT3/RET/CSF1R inhibitor in a Phase II trial. J Hematol Oncol. 2014;7(1):1-10. doi:10.1186/ s13045-014-0052-X

23. Harris PA, Boloor A, Cheung M, et al. Discovery of 5-[[4-[(2, 3-dimethyl-2 H-indazol-6-yl) methylamino]-2-pyrimidinyl] amino]-2-methylbenzenesulfonamide (Pazopanib), a novel and potent vascular endothelial growth factor receptor inhibitor. J Med Chem. 2008;51(15):4632-4640.

24. Kong LJ, Li H, Du Y-J, et al. Vatalanib, a tyrosine kinase inhibitor, decreases hepatic fibrosis and sinusoidal capillarization in CCl4-induced fibrotic mice. Mol Med Rep. 2017;15(5):2604-2610. doi:10.3892/mmr.2017.6325

25. Modi S, Kulkarni V. Vascular endothelial growth factor receptor (VEGFR-2)/KDR inhibitors: Medicinal Chemistry perspective. Med Drug Discov. 2019;2:100009. doi:10.1016/j.medidd.2019.100009 
26. Zuccotto F, Ardini E, Casale E, et al. Through the "gatekeeper door": exploiting the active kinase conformation. J Med Chem. 2010;53 (7):2681-2694. doi:10.1021/jm901443h

27. Lintnerová L, García-Caballero M, Gregáň F, et al. A development of chimeric VEGFR2 TK inhibitor based on two ligand conformers from PDB: 1Y6A complex-Medicinal chemistry consequences of a TKs analysis. Eur J Med Chem. 2014;72:146-159. doi:10.1016/j.ejmech.2013.11.023

28. Blanc J, Geney R, Menet C. Type II kinase inhibitors: an opportunity in cancer for rational design. Anticancer Agents Med Chem. 2013;13 (5):731-747.

29. Regan J, Pargellis CA, Cirillo PF, et al. The kinetics of binding to p38 MAP kinase by analogues of BIRB 796. Bioorg Med Chem Lett. 2003;13 (18):3101-3104. doi:10.1016/S0960-894X(03)00656-5

30. Abdullaziz MA, Abdel-Mohsen HT, El Kerdawy AM, et al. Design, synthesis, molecular docking and cytotoxic evaluation of novel 2-furybenzimidazoles as VEGFR-2 inhibitors. Eur J Med Chem. 2017;136:315-329. doi:10.1016/j.ejmech.2017.04.068

31. Wu S, Chen JJ, Kudelka A, et al. Incidence and risk of hypertension with sorafenib in patients with cancer: a systematic review and meta-analysis. Lancet Oncol. 2008;9(2):117-123. doi:10.1016/S1470-2045(08)70003-2

32. Wang Z, Xu J, Nie W, et al. Risk of hypertension with regorafenib in cancer patients: a systematic review and meta-analysis. Eur J Clin Pharmacol. 2014;70(2):225-231. doi:10.1007/s00228-013-1598-1

33. Uschner FE, Schueller F, Nikolova I, et al. The multikinase inhibitor regorafenib decreases angiogenesis and improves portal hypertension. Oncotarget. 2018;9(90):36220. doi:10.18632/oncotarget.26333

34. Motzer RJ, Nosov D, Eisen T, et al. Tivozanib versus sorafenib as initial targeted therapy for patients with advanced renal cell carcinoma: results from a Phase III randomized, open-label, multicenter trial. J Clin Oncol. 2012;30(15):277S. doi:10.1200/jco.2012.30.15_suppl.4501

35. Shahin MI, Abou El Ella DA, Ismail NSM, et al. Design, synthesis and biological evaluation of type-II VEGFR-2 inhibitors based on quinoxaline scaffold. Bioorg Chem. 2014;56:16-26. doi:10.1016/j.bioorg.2014.05.010

36. Akhtar R, Zahoor AF, Rasul A, et al. Design, synthesis, in-silico study and anticancer potential of novel n-4-piperazinyl-ciprofloxacin-aniline hybrids. Pak J Pharm Sci. 2019;32(5):2215-2222.

37. Murty M, Ramalingeswara Rao B, Katiki MR, et al. Synthesis of piperazinyl benzothiazole/benzoxazole derivatives coupled with 1, 3, 4-oxadiazole-2-thiol: novel hybrid heterocycles as anticancer agents. Med Chem Res. 2013;22(10):4980-4991. doi:10.1007/s00044-013-0510-y

38. Rejmund M, Mrozek-Wilczkiewicz A, Malarz K, et al. Piperazinyl fragment improves anticancer activity of Triapine. PLoS One. 2018;13(4): e0188767. doi:10.1371/journal.pone.0188767

39. Abou-Seri SM, Eldehna WM, Ali MM, et al. 1-Piperazinylphthalazines as potential VEGFR-2 inhibitors and anticancer agents: synthesis and in vitro biological evaluation. Eur J Med Chem. 2016;107:165-179. doi:10.1016/j.ejmech.2015.10.053

40. Alizadeh A, Moafi L. Simple access to spirooxadiazole compounds containing a quinoxaline moiety using a nitrile imine intermediate generated in situ. Heterocycl Commun. 2017;23(5):375-378. doi:10.1515/hc-2017-0084

41. Monge Vega A, Gil MJ, Basilio A, et al. 1-Hydrazinopyridazino [4, 5-b] quinoxaline, a new antihypertensive agent. Eur J Med Chem. 1986;21 (3):251-254.

42. Xie S, Li X, Yu H, et al. Design, synthesis and biological evaluation of isochroman-4-one hybrids bearing piperazine moiety as antihypertensive agent candidates. Bioorg Med Chem. 2019;27(13):2764-2770. doi:10.1016/j.bmc.2019.05.004

43. Jianzhi S, Qizeng W, Bin L, et al. Piperazine ferulate exerts antihypertensive effect and improves endothelial function in vitro and in vivo via the activation of endothelial nitric oxide synthase. Cell Mol Biol. 2019;65(3):119-124. doi:10.14715/cmb/2019.65.3.18

44. Zheng C-B, Gao W-C, Pang -P-P, et al. Synthesis and vasorelaxant evaluation of novel 7-methoxyl-2, 3-disubstituted-quinoxaline derivatives. Bioorg Med Chem Lett. 2021;36:127785. doi:10.1016/j.bmcl.2021.127785

45. Lee K, Jeong K-W, Lee Y, et al. Pharmacophore modeling and virtual screening studies for new VEGFR-2 kinase inhibitors. Eur J Med Chem. 2010;45(11):5420-5427. doi:10.1016/j.ejmech.2010.09.002

46. Xie -Q-Q, Xie H-Z, Ren J-X, et al. Pharmacophore modeling studies of type I and type II kinase inhibitors of Tie2. J Mol Graph Model. 2009;27 (6):751-758. doi:10.1016/j.jmgm.2008.11.008

47. Aziz MA, Serya RAT, Lasheen DS, et al. Discovery of potent VEGFR-2 inhibitors based on furopyrimidine and thienopyrimidne scaffolds as cancer targeting agents. Sci Rep. 2016;6(1):1-20. doi:10.1038/srep24460

48. Machado VA, Peixoto D, Costa R, et al. Synthesis, antiangiogenesis evaluation and molecular docking studies of 1-aryl-3-[(thieno [3, 2-b] pyridin-7-ylthio) phenyl] ureas: discovery of a new substitution pattern for type II VEGFR-2 Tyr kinase inhibitors. Bioorg Med Chem. 2015;23 (19):6497-6509. doi:10.1016/j.bmc.2015.08.010

49. Viegas-Junior C, Danuello A, da Silva Bolzani V, et al. Molecular hybridization: a useful tool in the design of new drug prototypes. Curr Med Chem. 2007;14(17):1829-1852. doi:10.2174/092986707781058805

50. Bosquesi PL, Melo TRF, Vizioli EO, et al. Anti-inflammatory drug design using a molecular hybridization approach. Pharmaceuticals. 2011;4 (11):1450-1474. doi:10.3390/ph4111450

51. Harmey JH, Bouchier-Hayes D. Vascular endothelial growth factor (VEGF), a survival factor for tumour cells: implications for anti-angiogenic therapy. Bioessays. 2002;24(3):280-283. doi:10.1002/bies.10043

52. Bagci E, Vodovotz Y, Billiar TR, et al. Bistability in apoptosis: roles of bax, bcl-2, and mitochondrial permeability transition pores. Biophys J. 2006;90(5):1546-1559. doi:10.1529/biophysj.105.068122

53. Brady HJ, Gil-Gómez G. Molecules in focus Bax. The pro-apoptotic Bcl-2 family member, Bax. Int J Biochem Cell Biol. 1998;30(6):647-650. doi:10.1016/S1357-2725(98)00006-5

54. Slee EA, Adrain C, Martin SJ. Executioner caspase-3,-6, and-7 perform distinct, non-redundant roles during the demolition phase of apoptosis. J Biol Chem. 2001;276(10):7320-7326. doi:10.1074/jbc.M008363200

55. Cohen GM. Caspases: the executioners of apoptosis. Biochem J. 1997;326(1):1-16. doi:10.1042/bj3260001

56. Chen J. The cell-cycle arrest and apoptotic functions of p53 in tumor initiation and progression. Cold Spring Harb Perspect Med. 2016;6(3): a026104. doi:10.1101/cshperspect.a026104

57. Shaw PH. The role of p53 in cell cycle regulation. Pathol Res Pract. 1996;192(7):669-675. doi:10.1016/S0344-0338(96)80088-4

58. Pellegata NS, Antoniono RJ, Redpath JL, et al. DNA damage and p53-mediated cell cycle arrest: a reevaluation. Proc Natl Acad Sci. 1996;93 (26):15209-15214. doi:10.1073/pnas.93.26.15209 
59. Teodoro JG, Evans SK, Green MR. Inhibition of tumor angiogenesis by p53: a new role for The Guardian of the genome. J Mol Med. 2007;85 (11):1175-1186. doi:10.1007/s00109-007-0221-2

60. Gerlier D, Thomasset N. Use of MTT colorimetric assay to measure cell activation. J Immunol Methods. 1986;94(1-2):57-63. doi:10.1016/0022$1759(86) 90215-2$

61. Wang J, Lenardo MJ. Roles of caspases in apoptosis, development, and cytokine maturation revealed by homozygous gene deficiencies. J Cell Sci. 2000;113(5):753-757. doi:10.1242/jcs.113.5.753

62. Lo KK-W, Lee TK-M, Lau JS-Y, et al. Luminescent biological probes derived from ruthenium (II) estradiol polypyridine complexes. Inorg Chem. 2008;47(1):200-208. doi:10.1021/ic701735q

63. Aborehab NM, Elnagar MR, Waly NE. Gallic acid potentiates the apoptotic effect of paclitaxel and carboplatin via overexpression of Bax and P53 on the MCF-7 human breast cancer cell line. J Biochem Mol Toxicol. 2021;35(2):e22638. doi:10.1002/jbt.22638

64. Elnagar MR, Walls AB, Helal GK, et al. Functional characterization of $\alpha 7$ nicotinic acetylcholine and NMDA receptor signaling in SHSY5Y neuroblastoma cells in an ERK phosphorylation assay. Eur J Pharmacol. 2018;826:106-113. doi:10.1016/j.ejphar.2018.02.047

65. Burnette WN. "Western blotting": electrophoretic transfer of proteins from sodium dodecyl sulfate-polyacrylamide gels to unmodified nitrocellulose and radiographic detection with antibody and radioiodinated protein A. Anal Biochem. 1981;112(2):195-203. doi:10.1016/0003-2697(81) 90281-5

66. Abd-Elhamid AI, El-Gendi H, Abdallah AE, et al. Novel nanocombinations of 1-tryptophan and 1-cysteine: preparation, characterization, and their applications for antimicrobial and anticancer activities. Pharmaceutics. 2021;13(10):1595. doi:10.3390/pharmaceutics13101 595

67. Dawoud N, El-fakharany E, El-gendi H, et al. Consolidated antimicrobial and anticancer activities through newly synthesized novel series of pyrazoles bearing indazolylthiazole moiety: characterization and molecular docking. Egypt $J$ Chem. 2021;64(11):5-6. doi:10.21608/ ejchem.2021.83623.4104

68. Abdallah AE, Alesawy MS, Eissa SI, et al. Design and synthesis of new 4-(2-nitrophenoxy)benzamide derivatives as potential antiviral agents: molecular modeling and in vitro antiviral screening. New J Chem. 2021;45(36):16557-16571. doi:10.1039/D1NJ02710G

Drug Design, Development and Therapy

\section{Publish your work in this journal}

Drug Design, Development and Therapy is an international, peer-reviewed open-access journal that spans the spectrum of drug design and development through to clinical applications. Clinical outcomes, patient safety, and programs for the development and effective, safe, and sustained use of medicines are a feature of the journal, which has also been accepted for indexing on PubMed Central. The manuscript management system is completely online and includes a very quick and fair peer-review system, which is all easy to use. Visit http://www.dovepress.com/testimonials.php to read real quotes from published authors.

Submit your manuscript here: https://www.dovepress.com/drug-design-development-and-therapy-journal 